\title{
FARKLI FIKHÎ HÜKÜMLERİN TEZAHÜRÜNDE HADISLERIN ROLÜ: GAYLÂN B. SELEME RIVAYETİ ÖRNEĞİ
}

\section{Fikret Özçelik*}

\section{$\ddot{O} z$}

Bu çalışmada, Gaylân b. Seleme'nin Müslüman olduğunda on kadınla evliyken, Hz. Peygamber'in (s.a.s.) kendisine hanımlarından dördünü tutmasını, geri kalanları da boşamasını emrettiği rivayet ele alınmıştır. Bu bağlamda söz konusu rivayetin sıhhati ile ilgili yapılan tartışmalar ve buna bağlı olarak fikhî hükümlere değinilmiştir. Zira Müslüman olmadan önce dörtten fazla kadınla evli olan kişinin durumu ile ilgili birbiriyle çelişen iki farklı görüş öne sürülmüştür. Birinci görüşe göre bu durumda olan kişi, Müslüman olduktan sonra hanımlarından istediği dördünü yanında tutacak; diğerlerini ise zorunlu olarak boşayacaktır. İkinci görüşe göre eğer birden fazla kadının nikâhı bir akitte kıyılmışsa bütün kadınların nikâhları geçersiz olur ve boş olurlar. Ancak kadınların nikâhları farklı akitlerde kıyılmışsa o zaman kişinin ilk dört hanımını tercih etmesi diğerlerini ise boşaması gerekmektedir. İmam Şâfiî başta olmak üzere bazı âlimler Gaylân b. Seleme rivayetinden hareketle birinci görüşü; İmam Ebû Hanife gibi bazı âlimler ise söz konusu rivayeti muallel kabul etmiş ve ikinci görüşü savunmuşlardır.

Anahtar Kelimeler: Hadis, Gaylân b. Seleme, Çok eşlilik, Nikâh, Fıkıh.

\section{THE ROLE OF HADITHS IN THE MANIFESTATION OF DIFFERENT ISLAMIC JURISPRUDENTIAL PROVISIONS:}

\section{THE EXAMPLE OF GHAYLĀN B. SALAMA NARRATIVE}

\begin{abstract}
In this study, narrative about Ghaylān b. Salama was married to ten women when he became a Muslim. Thereupon the Prophet (pbuh) ordered him to stay married to four of his wives and divorce the rest. In this context, the current debates on the accuracy of the narrative and the related Islamic jurisprudential provisions are discussed. Because two contradictory opinions were asserted regarding the situation of the person who married more than four women before becoming a Muslim. According to the first opinion, a person who is in this situation will keep four of his wives after he becomes a Muslim and will divorce the others. According to the second, if the man gets married more than one woman under a single contract, all women's marriage will be invalid, and they will
\end{abstract}

Article Types / Makale Türü: Research Article / Araştırma Makalesi

Received / Makale Geliș Tarihi: 31.08.2019 Accepted / Kabul Tarihi:12.12.2019

Doi: $10.26791 /$ sarkiat.613767

* Dr. Öğr. Üyesi, Mardin Artuklu Üniversitesi İslami İlimler Fakültesi, ozcelik.21@hotmail.com ORCID ID: https://orcid.org/0000-0001-5015-6167 
be divorced. However, if they are married under different contracts, then the person should prefer the first four women and divorce the others. Some scholars, Imam Shafi'i in particular, defended the first opinion, whereas the others such as Imam Abu Hanifa, accepted this narrative as defected and defended the second opinion.

Keywords: Hadith, Ghaylân b. Salama, Polygamy Marriage, Wedding, Fiqh

\section{GíRiş}

Hadis, İslam kültür ve ilim geleneğinde Kur'an'dan sonra ikinci kaynak olarak telakki edilmiştir. Ayrıca hadislerle ilgili geçmişte olduğu gibi günümüzde de birçok tartışmaya şahit olunmaktadır. Hadis ilmi için en önemli problemlerden biri, rivayetlerin sıhhati meselesidir. Nitekim tarihi süreç içerisinde rivayetlerin sıhhati ile ilgili farklı yaklaşım ve eğilimler söz konusudur. Bu farklı yaklaşım ve eğilimler, geçmişte olduğu gibi günümüzde de devam etmektedir. Hadisle ilgili var olan bu sorun, Müslüman bilginleri meşgul ettiği gibi Batılı bilginlerin de dikkatini çekmektedir. Ancak Müslüman ve Batılı bilginlerin, hadislerin sıhhatini ele alış biçiminin ve temel düşüncelerinin aynı olmadığı söylenebilir. Zira Müslümanlar daha çok hadisin kaynağını ve nisbetini ele alırken; Batılı bilginler hadislerin hangi tarihte ve kimin tarafidan tedavüle sokulduğu meselesini ele almaktadir.

Sünneti ve hadisleri anlama çabasının Hz. Peygamber (s.a.s.) döneminden günümüze kadar devam ettiğini söylemek mümkündür. Öyle ki sahabe döneminden itibaren sünnete ve hadislere karşı iki farklı eğilimin geliştiği görülmektedir. Bunlardan birincisi lafzı ve rivayeti öncelemiş, ikincisi ise hadisleri ele alırken Hz. Peygamber' in ne dediğini değil, ne demek istediğini incelemiş ve buna öncelik vermiştir. ${ }^{1}$ Sahabe döneminden başlayan bu iki eğilimin temsilcileri her dönemde bazı farklılıklarla beraber etkinliklerini sürdürmüşlerdir. Ayrıca naslara dayanan yorumlarda ittifaktan söz etmek de mümkün değildir. Zira metinleri anlama ve yorumlamada muhteva tenkidi gibi iç faktörlerle beraber sened tenkidi denilebileceği diş faktörlerin etkisi de inkâr edilemez. ${ }^{2}$ Bu bağlamda tarihte Ehl-i Re'y ve Ehl-i Hadis'in ${ }^{3}$ varlığı bu hakikatin bir tezahürüdür denilebilir. Ayrıca bu iki farklı yaklaşımın varlığının rivayetlere dayanan birçok fikhî meselede ihtilafa yol açtığı da bir hakikattir.

Hadislerin sıhhati bağlamında tartışılan ve günümüzde de canlılığını koruyan en önemli husus, sened tenkidiyle beraber muhteva tenkidinin yapılıp yapılmadığ meselesidir. $^{4}$

\footnotetext{
1 Mehmet Görmez, Sünnet ve Hadisin Anlaşılması ve Yorumlanmasında Metodoloji Sorunu, 5. Bask1 (Ankara: OTTO Yayınları, 2014), 77-78.

2 Dış tenkit ve iç tenkit için bkz. Enbiya Yıldırım, Hadiste Metin Tenkidi (İstanbul: Rağbet Yayınları, 2009), 502-518; Raşit Küçük, "Metin", Türkiye Diyanet Vakfi İslâm Ansiklopedisi (Ankara: TDV Yayınları, 2004), 29: 413.

3 İlk dönem Ehl-i Re'y ve Ehl-i Hadis’in tartışmaları için bkz. Mehmet Özşenel, İlk Dönem Hadis-Rey Tartışmaları Şeybânî Örneği, 2. Baskı (İstanbul: İFAV Yayınları, 2017); Kadir Gürler, Ehl-i Hadisin Düşünce Yapısı İlk Dönem Ehl-i Hadis Örneği (Bursa: Emin Yayınları, 2007); M. Emin Özafşar, "Kültür Tarihimizde Rey-Eser Çatışması (Dini, Psikolojik, Sosyo-Kültürel Temelleri)", Ankara Üniversitesi Illahiyat Fakültesi Dergisi, 2000/41, (2000): 225-273; Ahmet Uyarı, "Hadisleri/Sünneti Anlamada Farklı Yaklaşımlar (Ehl-i Hadis Ve Ehl-i Re’y Ekolleri)", Bilimname 2004/2 (Haziran 2004): 29-44; Uğur Erman, Ehl-i Hadîs ve Ehl-i Re'y Arasında Yaşanan Polemiklerin Cerh ve Ta'dîl İlmine, Dönemin Te'lîfâtına ve Sosyal/Beşerî İlişkilere Yansıması (Hicrî III. Asır), e-Şarkiyat İlmi Araştırmalar Dergisi, 9/18 (Kasim 2017): 990-1010.

${ }^{4}$ Metin tenkidi kavramı yerine muhteva/içerik tenkidi kavramı kullanımı için bkz. Salahattin Polat, Metin Tenkidi (İstanbul: İFAV Yayınları, 2010), 25; Zişan Türcan, "Hadisçilerin Rivayet Telakkisi ve İçerik
} 
Rivayetlere verilen sıhhat hükmünde, muhteva tenkidine başvurulmadığını iddia edenlere göre hadis usûlü ilmi, sadece sened usûlü ilmi olduğu için doğal olarak isnad tenkidine önem verilmiş ve bunun üzerinde durulmuştur. muhteva tenkidinin yapıldığını iddia edenler ise sahih hadisin tanımında yer alan illet ve şâz konusuna dikkat çekmişlerdir. ${ }^{5}$ Aynı şekilde herhangi bir rivayetin Hz. Peygamber'e (s.a.s.) ait olabilmesi için şu kriterlere de başvurulmuştur: Rivayeti Kur'an'a, dinin temel gaye ve hedeflerine, sahih sünnete, aynı konuda sabit olan diğer sahih rivayetlere, tarihi gerçekliklere, dil kurallarına, akıl ve mantık ilkelerine, maruf olan örfe, evrensel insani değerlere ve ahlak ilkelerine arz etme. ${ }^{6}$

Hadis usulü ilminin senedi öncelemesi doğru ve tabiîdir. Zira sened sayesinde metnin aidiyeti ortaya konulmakta; metnin aidiyeti belli olduktan sonra metin de muhteva açısından ele alınmakta, anlama ve yorumlama çabası başlamaktadır. Hz. Peygamber'e aidiyeti kesin olmayan bir metni yorumlama faaliyeti, anlam doğru olsa bile yanlış sonuçlara yol açabilir. Ancak bu gerçeğe rağmen bir metni anlamanın ölçüsünü sadece senede bağlamak da doğru bir yaklaşım değildir. Zira herhangi bir rivayetin, sened açısından sahih olsa bile metin açısından sorunlu olması her zaman imkân dâhilindedir. ${ }^{7}$ Bundan olsa gerektir ki, İbnü'l-Cevzî'nin şu tespiti adeta bir kaide mesabesinde değerlendirilebilir: "Bazen isnadın tamamı güvenilir olduğu halde hadis mevzu veya maklûb olabilmekte ya da hadiste tedlis bulunabilmektedir." İbnü'l-Cevzî'nin bu sözünden de anlaşıldığı gibi senedin sıhhati metnin sıhhatini zorunlu kılmamaktadır. Zira metni rivayet edenlerin, beşer olmaları hasebiyle unutkanlık, vehim ve yanlış ezberleme gibi hatalardan beri olmaları mümkün değildir.Ayrıca illet mevzusunun, İbnü'l-Cevzî tarafından dile getirilen tespitinin uygulandığı en geniş alan olduğu söylenebilir; zira rivayetlerde tespit edilen illet, sahih bir rivayeti bile sahihlik derecesinden düşürebilmektedir. ${ }^{9}$ Nitekim klasik hadis usûlü kaynaklarında genel olarak sahih hadisin tanımı; "adalet ve zabt sahibi olan râvilerin muttasıl bir isnatla rivayet ettikleri şaz ve muallel olmayan hadis" ${ }^{10}$ şeklinde yapılmıştır. Sahihin tanımından da

Tenkidi Meselesi”, Türk Akademik Araştırmalar Dergisi, 4/2 (2019): 299-316; Jonathan Brown, "Erken Dönem Hadis Münekkitlerinin Metin Tenkidi Yaptığını Nasıl Biliyoruz ve Bulmak Niçin Bu Kadar Zor?”, trc. Salih Kesgin, Usûl: İslam Araştırmaları, 25 (Ocak-Haziran 2016): 265-310.

${ }^{5}$ Yavuz Köktaş, "Hadiste İllet: Ümmetin Faziletiyle İlgili Bir Hadîsin Değerlendirilmesi”, Ç.Ü. İlahiyat Fakültesi Dergisi, 2/2 (Temmuz-Aralık 2002): 42.

6 Ahmet Keleş, Hadis İlminde Metin Tenkidi Örnekleri (Ankara: Fecr Yayınlar1, 2017), 24; Mustafa Ertürk, Metin Tenkidi, 2. Baskı. (Ankara: Fecr Yayınları, 2011), 67-114. Ayrıca metin tenkidinin yeterince yapıldığını iddia edenlerin yaklaşımları ile metin tenkidinin ihmal edildiğini iddia edenlerin yaklaşımları ve söylemeleri için bkz. Yıldırım, Hadiste Metin Tenkidi, 37-54. Misfir b. Gurmullah edDümeynî’ye göre ilk dönem müsannif sahipleri eserlerini meydana getirirken sened ve metin tenkidini yapmışlardır. Ancak söz konusu âlimler tenkit ölçülerini açıklamamışlardır. Misfir b. Gurmullah edDümeynî, Hadis'te Metin Tenkidi Metodları, trc. İlyas Çelebi vd., (İstanbul: Kitabevi Yayınları, 1997), 101-102. Ayrıca Muhaddis ve Fakihlerin metin tenkidi ölçüleri için bkz., Misfir b. Gurmullah, Hadis'te Metin Tenkidi Metodlarl, 102-404.

${ }^{7}$ Köktaş, "Hadiste İllet: Ümmetin Faziletiyle İlgili Bir Hadîsin Değerlendirilmesi”, 42.

${ }^{8}$ Ebü'l-Ferec Abdurrahman b. Ali b. el-Cevzî, Kitâbü 'l-mevzûât (Beyrut: Dâru'l-Fikr, 1983), 1: 99.

${ }^{9}$ Köktaş, "Hadiste İllet: Ümmetin Faziletiyle İlgili Bir Hadîsin Değerlendirilmesi" 42.

10 Bkz. Ebû Amr Takıyyüddîn Osmân b. Salâhiddîn Abdirrahmân b. Mûsâ eş-Şehrezûrî, Ma 'rifetu ulûmi'l-hadîs, 3. Baskı (Beyrut: Dâru'l-Kütübi'l-İlmiyye, 2010), 18; Ebü'l-Fazl Şihâbüddîn Ahmed b. Alî b. Muhammed el-Askalânî, Nüzhetü'n-nazar (Kahire: Dâru İbn Receb, 2006), 58; Ebü’l-Fazl Zeynüddîn Abdürrahîm b. el-Hüseyn b. Abdirrahmân el-Irâkī, et-Takyîd ve'l-îdâh, 5. Baskı (Beyrut: Müessesetü'lKütübi's-Sakâfiyye, 1997), 24. Sahih hadisin bu tanımının ilk defa İbnü's-Salâh tarafından yapıldığg söylenebilir. Ayrıca onun tarafından şekillendirildiği ve formüle edildiği tanım, kendisinden sonra gelen ulema tarafindan da benimsenmiş ve kabul görülmüştür. Şüphesiz İbnü's-Salâh'ın, kendisinden önce 
anlaşıldığı gibi herhangi bir rivayete sahih hükmünün verilebilmesi için söz konusu rivayetin, şâz ve muallel olmaması gerekmektedir. Dolayısıyla sahih hadisin tanımında yer alan illet ve şaz kavramlarının, rivayete verilen sahih veya zayıf hükmünün belirlenmesinde önemli iki öncül vasıf olduğu kabul edilmektedir. Bundan dolayı her iki kavram, hadis ve fıkıh ilminin en başta gelen konuları arasında yer almıştır. Bu bağlamda âlimlerin, farklı fikhî sonuçlarına götüren sebeplerin başında rivayetlerin illetli ve şaz olup olmadığına bağlı olduğu anlaşılmaktadır. ${ }^{11}$

$\mathrm{Bu}$ gerçeklikten hareketle bu çalışmada rivayetlere verilen farklı sihhat hükümlerinden kaynaklanan ihtilaflar, Gaylân b. Seleme (ö. 23/644) rivayeti bağlamında ele alınacaktır. Ayrıca rivayetin sıhhati ile ilgili var olan farklı yaklaşımlarının, âlimlerin fıkhî görüşlerine nasıl yansıdığ 1 bu rivayet bağlamında tespit edilmeye çalışılacaktır. Böylelikle rivayetlerin, âlimlerin fetva ve görüsslerinde ne kadar etkili olduğunu tikel bir örnek üzerinde ortaya konmaya çalış1lacaktır.

\section{GAYLÂN B. SELEME RIVAYETI VE ÂLIMLERIN RIVAYETLE ILGILI YAKLAŞIMLARI}

Hz. Peygamber'in (s.a.s.) gönderildiği dönemde birden çok evliliğin var olduğu bilinen bir hakikattir. ${ }^{12}$ Aynı şekilde bazı kişilerin dörtten fazla kadınla evli oldukları da

yapılan tanımlardan faydalandığı da bir hakikattir. Bkz. Mehmet Bilen, "Sahih Hadisin Tanımı Üzerine", Dicle Üniversitesi İlahiyat Fakültesi Dergisi 1 (1999): 249.

İbnü's-Salâh'tan önce sahih hadisin tanımı konusunda âlimlerin ittifakından söz etmek pek mümkün değildir. Mesela İmam Şâfî̂’nin (ö. 204/820) tarifinde şu hususların ön plana çıktığı görülmektedir:

- Senedin muttasil olmasi,

- Râvinin sika ve sözünde doğru olması,

- Râvinin mana ile rivayette bulunuyorsa hadisin lafzında yapılabilecek herhangi bir değişikliğin yol açacağı anlam bozukluğuna vakıf olması,

- Ezberinden rivayet ediyorsa duyduğu gibi rivayette bulunacak kadar hıfzı sağlam olması; kitaptan rivayet ediyorsa ise kitabını iyi koruyan birisi olmalı,

- Râvinin müdellis olmamas1,

- Sika râvilere muhalefet etmemesi. Geniş bilgi için bkz. Ebû Abdillâh Muhammed b. İdrîs b. Abbâs eşŞâfîi, er-Risâle, nşr. Ahmed Şakir (Kahire: Dâru'l-Hadîs, 2016), 430-431.

Ebû Ali Cübbâî'ye (ö. 303/916) nispet edilen görüşe göre kendisi sahih hadis olarak kabul edilen adalet sahibi bir râvinin rivayeti kabul edilebilmesi için şu şartlardan biri olmalıdır:

- Başka bir âdil râvi tarafindan desteklenmeli,

- Kitap veya sünnetin zahirine uygun olmalı,

- Sahabiler arasında yaygın olmalı veya bazı sahabiler onunla amel etmiş olmalı. Bkz. Tahir el-Cezâirî, Tevcîhü'n-nazar ilâ usûli'l-eser, nşr. Abdulfettâh Ebû Gudde, 2. Bask1 (Beyrut: Dâru'l-Beşâiri'lİslâmiyye, 2009), 181.

Hâkim en-Nîsâbûrî (ö. 405/1014) sahih hadisi şöyle tanımlamıştır: "Kendisinden iki tâbiînin rivayet etmesiyle cehalet vasfı zail olmuş bir sahabinin rivayet etmesi ve günümüze kadar hadis ehlinin kabul ettiği rivayettir." Geniş bilgi için bkz. Ebû Abdillâh Muhammed b. Abdillâh b. Muhammed el-Hâkim enNîsâbûrî, Ma 'rifetü ulûmi'l-hadîs (Beyrut: Dâru'l-Kütübi'l-İlmiyye, 1977), 62.

Hatîb Bağdâdî de (ö. 463/1071) sahih hadisin tanımında rivayetin muttasıl olması ve senedinde mechul ve cerh edilen râvinin olmamasına dikkat etmiştir. Bkz. Hatîb el-Bağdâdî, el-Kifâye fì ilmi'ri-rivâye (Beyrut: Dâru'l-Kütübi'l-İlmiyye, 2006), 23.

11 Muhittin Düzenli, Hadislerde Gizli Kusurlar (İstanbul: İSAM Yayınları, 2016), 21. İllet vasfindan dolayı zayıf kabul edilen ve âlimlerin ihtilaflarına yol açan rivayetlerin örneği için bkz. Mâhir Yâsîn Fahl, Eseru ileli'l-hadîs fî ihtilâfi'l-fukahâ (Ammân: Dâru Ammâr, 2000).

12 İlk dönem siyer müelliflerden Muhammed b. Habîb (ö. 245/860) el-Muhabber adlı eserinde; "Üç defadan fazla evlenen kadınların isimleri” diye bir başlık açmış ve bu başlığın altında uzun bir liste sunmuştur. Geniş bilgi için bkz. Muhammed b. Habîb, el-Muhabber, nşr. Ilse Lichtenstädter (Beyrut: Dâru'l-Âfâki'l-Cedîde, ts.), 435-455. Bazı araştırmacılara göre birden çok evlilik fazla yaygın olmayıp daha çok toplumda belli bir statüye sahip olanlar arasında vardı. Nitekim Adnan Demircan konuyla ilgili şu açıklamayı yapmıştır: "Çok kadınla evliliğin, erkeğin sosyal ve ekonomik durumuyla yakından ilgisi 
görülmekteydi. Ancak bu kişiler Müslüman olduktan sonra Hz. Peygamber'in, kendilerine sadece dört kadınla evli kalabileceklerini, dörtten fazla olanları ise boşamalarını emrettiği nakledilmektedir. ${ }^{13}$

Konuyla ilgili en meşhur olan ve üzerinde tartışma yapılan rivayetlerden birisi Gaylân b. Seleme'nin (ö. 23/644) rivayetidir. Rivayet edildiğine göre Gaylân b. Seleme Müslüman olduğunda on kadınla evliydi. Bunun üzerine $\mathrm{Hz}$. Peygamber (s.a.s.) kendisine hanımlarından dört tanesini tutmasını, geri kalanları da boşamasını emretti. ${ }^{14}$

Biz de âlimlerin ihtilaf nedenlerini ve söz konusu rivayetin âlimlerin konuyla ilgili görüşleri üzerindeki etkisini araştırıp rivayetle ilgili kanaatimizi sonuç kısmında ifade edeceğiz.

\subsection{Gaylân b. Seleme Rivayetini Sahih Kabul Eden Âlimler}

Gaylân b. Seleme rivayetini sahih kabul eden âlimlerin başında İmam Şâfiî gelmektedir. Kendisi el-Ümm adlı eserinde söz konusu rivayete yer verip onu farklı varyantlarla rivayet etmiş ve bütün tarikleri muttasıl olarak nakletmiştir. ${ }^{15}$ Nitekim kendisi söz konusu rivayetin İbn Uleyye - Ma'mer - Zührî - Sâlim - Abdullah b. Ömer tarafindan nakledildiğini söylemiştir. Dolayısıyla rivayet bu haliyle muttasıl olup delil değerine sahiptir. Zira İmam Şâfîî’nin senedinde yer alan İsmail b. İbrahim b. Uleyye , ${ }^{16}$ Ma ‘mer b. Râşid (ö. 153/770), ${ }^{17}$ İbn Şihâb ez-Zührî (ö. 124/742) ${ }^{18}$ ve Sâlim b. Abdullah b. Ömer (ö. 106/725), ${ }^{19}$ hadis münekkitleri tarafından güvenilir kabul edilmiştir. Ayrıca Beyhâkî'nin Ebû Abdillah'tan yaptığı nakle göre söz konusu rivayette yer alan râviler sika olduğunu ve rivayetleri delil olabileceğini söylemiştir. ${ }^{20}$ Ayrıca İmam Şâfiî adı geçen eserinde İmam Mâlik'in Zührî’nin şöyle dediğini de aktarmıştır: "Sakîf kabilesinde on kadınla evli olan bir adam Müslüman oldu. Bunun üzerine $\mathrm{Hz}$. Peygamber (s.a.s.) kendisine hanımlarından dördünü yanında tutmayı, diğerlerini de boşamayı emretti." ${ }^{21} \mathrm{Bu}$ rivayette her ne kadar Gaylân'ın ismi geçmese de, yukarıda geçen rivayet dikkate alındığında bu adamın Gaylân b. Seleme olduğu muhtemeldir.

vardı. Tespit edebildiğimiz kadarıyla Câhiliye dönemiyle İslâm’ın ilk yıllarında genç erkekler arasında tek kadınla evlilik yaygındı; ancak yaş ilerledikçe kişinin, kabîlesi içindeki konumuna paralel olarak taşıdığı sorumluluk ve ekonomik durumunun düzelmesi, yeni evlilikler yapmasını mümkün, hatta gerekli hale getirebiliyordu. Yine de bunun istisnâlarının bulunduğunu hesaba katmak gerekir. Bazen genç biri de, evlenmesi yasak olmayan yakınlarından dul kalan bir kadını, ikinci eş olarak nikahlayabiliyordu. Tatbikatı denetleyen bir mekanizma olmadığı için, örfü zorlamak her zaman mümkündü. Öte yandan ikiden fazla kadınla evlilik uygulamasının genellikle liderler için söz konusu olduğu söylenebilir." Bkz. Adnan Demircan, “Câhiliyye ve Hz. Peygamber Döneminde Çok Kadınla Evlilik”, İstem 1/2 (2003): 17.

${ }^{13}$ Habîb, el-Muhabber, 357.

${ }^{14}$ Şâfiî, el-Ümm (Beyrut: Dâru'l-Ma'rife, 1990), 4: 281, 5: 53-175-177, 8: 381; Ebû Abdillâh Muhammed b. Sa'd b. Menî‘ el-Kâtib el-Hâşimî el-Basrî el-Bağdâdî, et-Tabakâtü’l-kübrâ, nşr, İhsân Abbâs (Beyrut: Dâru Sadr, 1968), 6: 46-47; Ebû Bekr Ahmed b. Hüseyn b. Ali el-Beyhakî, Ma 'rifetü's-sünen ve'l-asâr, nşr. Abdülmu'tî Emîn Kale‘cî (Dımeşk: Dâru Kuteybe, 1991), 10: 137.

15 Şâfî̀, el-Ümm, 4: 281, 5: 53-175-177, 8: 381.

16 Bkz. Ebû Muhammed Abdurrahmân b. Muhammed b. İdrîs er-Râzî, el-Cerh ve 't-ta 'dîl, nşr. Mustafa Abdulkâdir Atâ, 2. Bask1 (Beyrut: 2010), 2: 153; Ebû'l-Haccâc Cemâlüddîn Yûsuf b. Abdirrahmân b. Yûsuf el-Mizzî, Tehżîü̈l-Kemâl fî esmâ'i'r-ricâl, nşr. Beşşâr Avvâd Marûf (Beyrut: Müessesetü'rRisâle, 1980), 3: 29.

17 İbn Ebî Hâtim, el-Cerh ve 'ta 'dîl, 8: 255; Mizzî, Tehzîibü'l-Kemâl fî esmâ 'i 'r-ricâl, 28: 303-312.

18 İbn Ebî Hâtim, el-Cerh ve 'ta 'dîl, 8: 71; Mizzî, Tehzîibü'l-Kemâl fî̀ esmâ 'i'r-ricâl, 26: 419-443.

19 İbn Hacer, Tehzîbü't-Tehzîb (Beyrut: Dâru'l-Fikr, 1984), 3: 436-438.

${ }^{20}$ Bkz. Beyhakî, el-Hilâfiyat beyne'l-imâmeyni eş-Şâfî̀ ve Ebî Hanîfe ve ashâbihî (Kâhire: er-Ravda, 2015), 6: 101.

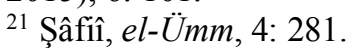


Gaylân b. Seleme rivayetini sahih kabul eden âlimlerden birisi de Ahmed b. Hanbel'dir (ö. 241/855). Kendisi söz konusu rivayeti dört farklı senedle nakletmiştir. Ayrıca Ahmed b. Hanbel her dört rivayete Zührî, Sâlim ve Abdullah b. Ömer aracillğıyla muttasil olarak eserinde yer vermiştir.

Ahmed b. Hanbel'in naklettiği üç rivayet şu şekildedir: Gaylân b. Seleme Müslüman olduğunda on kadınla evli idi. Bunun üzerine Hz. Peygamber kendisine şöyle dedi: "Hanımlarından dördünü yanında tut." Görüldüğü gibi bu rivayet muttasıl olarak nakledilmekte ve sadece Gaylân'ın Müslüman olduğunda kaç hanımla evli olduğunu ve Hz. Peygamber'in ona neyi emrettiğini içermektedir. ${ }^{22}$

Konuyla ilgli rivayetlerden biri de şu ifadelerle nakledilmiştir: Gaylân b. Seleme Müslüman olduğunda on kadınla evli idi. Bunun üzerine Hz. Peygamber kendisine şöyle dedi: "Hanımlarından dördünü yanında tut." Hz. Ömer zamanında Gaylân bütün hanımlarını boşadı ve malını da çocukları arasında taksim edip dağıttı. Gaylân'ın bu durumu Hz. Ömer'e ulaştı. Bunun üzerine Hz. Ömer kendisine şöyle dedi: “Sanki şeytan senin ölüm haberini işitip senin kalbine atmış ve belki de uzun yaşayamayacağına inanmışsın; Allah'a yemin olsun ki ya hanımlarına dönecek ve malını geri alacaksın veya Ebû Rigâl'ın kabri recmedildiği gibi senin kabrini de recmedeceğim." 23 Ahmed b. Hanbel'in rivayet ettiği bu nakilde Gaylân b. Seleme ile ilgili farklı zamanlarda gerçekleşen iki olay birleştirilmiş ve bir senedle rivayet edilmiştir.

İbn Mâce (ö. 273/887) ve Tirmizî (ö. 279/892), Sünen adlı eserlerinde söz konusu rivayete yer vermişlerdir. İbn Mâce rivayeti Hakîm, Muhammed b. Cafer, Ma'mer b. Râşid, Zührî, Sâlim ve Abdullah b. Ömer aracılığıyla rivayet etmiştir., ${ }^{24}$ Tirmizî ise rivayeti Abde - Saîd b. Arûbe - Ma'mer - Zührî - Sâlim - Abdullah b. Ömer'in aracılığıyla rivayet etmiştir. Ayrıca Tirmizî’ye göre İmam Şâfiî, Ahmed b. Hanbel ve İshâk bu rivayetle amel etmişlerdir. ${ }^{25}$

Söz konusu rivayete geniş bir şekilde değinen âlimlerin başında Dârekutnî (ö. 385/995) gelmektedir. Kendisi rivayeti altı tarikle nakletmiştir. Dârekutnî’nin bir tariki şu şekildedir: Muhammed b. Amr el-Bühterî - Ahmed b. Halîl - Vâkidî - Abdullah b. Ca'fer - Abdullah b. Ebû Süfyân - Ebû Süfyân - Abdullah b. Abbâs: "Gaylân b. Seleme Müslüman olduğunda on kadınla evliydi. Bunun üzerine Hz. Peygamber (s.a.s.) kendisine, hanımlarından dördünü yanında tutmayı diğerlerini de boşamasını emretti." ${ }^{26}$

Konuyla ilgili Dârekutnî'nin bu rivayetinin çok önemli olduğunu belirtmek isteriz. Zira tespit edebildiğimiz kadarıyla Gaylân b. Seleme'nin evlililiği ile ilgili bütün rivayetleri Zührî, o da bazen Sâlim b. Abdullah aracılığıyla Abdullah b. Ömer'den, bazen de Osman b. Muhammed b. Ebî Süveyd'den veya kendisi munkatı' olarak rivayet etmiştir. Bu bağlamda daha sonra değineceğimiz üzere Gaylân'ın kıssasının ele alındığı rivayete yapılan itirazların büyük bir kısmı, İbn Şihâb'ın bu rivayeti Sâlim aracılığıyla Abdullah b. Ömer'den muttasıl olarak rivayet etmediğine yöneliktir. Ancak Dârekutnî’nin bu

\footnotetext{
${ }^{22}$ Ebû Abdillâh Ahmed b. Muhammed b. Hanbel eş-Şeybânî el-Mervezî, Müsned (Beyrut: Müessesetü’rRisâle, 2001), 4: 327; 487.

23 Ahmed b. Hanbel, Müsned, 4: 337.

${ }^{24}$ Ebû Abdillâh Muhammed b. Yezîd Mâce el-Kazvînî, "Nikah", 40, nşr. Şuayp Arnavut vd. (Beyrut: Dâru'r- Resâili'l-Alemiyye, 2009).

${ }^{25}$ Ebû Îsâ Muhammed b. Îsâ et-Tirmizî, “Nikah”, 33, nşr. Beşşâr Avvâd Marûf (Beyrut: Dâru'l-Garbi’lİslâmî, 1998).

${ }^{26}$ Ebü'l-Hasen Alî b. Ömer b. Ahmed ed-Dârekutnî, Sünen (Beyrut: Müessetü’r-Risâle, 2004), 4: 403.
} 
rivayetinde ne Zührî ne de Sâlim ve Abdullah b. Ömer yer almaktadır. Dolayısıyla bunun da söz konusu rivayetin sahih olma ihtimalini güçlendiren önemli bir faktör olduğunu düşünüyoruz.

Dârekutnî'nin ikinci tariki de; İbrahim b. Hammâd ve Muhammed b. Mahled - Hasan b. Arefe - Mervân b. Muâviye el-Fezârî - Zührî - Sâlim - Abdullah b. Ömer şeklindedir. ${ }^{27}$ $\mathrm{Bu}$ tarikte dikkat çekilen önemli hususun, senedde Ma'mer b. Râşid'in yer almamasıdır. Daha sonra değineceğimiz üzere söz konusu rivayete yapılan temel itirazlarından birisinin Ma'mer'e yönelik olduğu görülmektedir. Çünkü itirazda bulunanlara göre Gaylân'ın kıssası ile ilgili iki farklı rivayet Zührî'den nakledilmiştir. Birincisi konu ettiğimiz rivayet, bu rivayet de munkatı' olarak nakledilmiştir. İkincisi ise Gaylân'ın Hz. Ömer zamanında eşlerini boşadığı ile ilgili rivayettir. Bu ise Zührî, Sâlim ve Abdullah b. Ömer aracılığıyla muttasıl olarak rivayet edilmiştir. Ancak Ma'mer, bu iki rivayeti karıştırmış, munkatı' olan rivayeti muttasıl olanın senediyle nakletmiştir. ${ }^{28} \mathrm{Bu}$ bağlamda Zührî'nin yer alıp Ma'mer'in olmadığı ve muttasıl olan Dârekutnî'nin bu rivayetinin bu açıdan önemli olduğu görülmektedir. ${ }^{29}$ Zira bu tariklerden yola çıkılarak Gaylân b. Seleme rivayetinin muttasıl ve dolayısıyla sahih olduğu söylenebilir. Çünkü bu rivayetle ilgili itirazların iki noktada yoğunlaştığı görülmektedir. Bunlardan birinci Zührî'nin bu rivayeti munkatı' olarak nakletmesi, ikincisi ise rivayetteki hatanın Ma'mer b. Raşid'den kaynaklı olduğu iddiasıdır. Ancak Dârekutnî'nin rivayet ettiği bazı tariklerde ne Zührî ne de Ma'mer yer almaktadır. Mesela bir rivayette Zührî yerine Serrâr b. Müceşşir bulunmaktadır. Bu râvi de hadis münekkitleri tarafından güvenilir kabul edilmektedir. ${ }^{30}$ Dolayısıyla Zührî ve Ma'mer bağlamında yapılan itirazların pek de anlamlı olmadığı anlaşılmaktadır. Zührî ile ilgili şu da denilebilir; kendisi bu rivayeti hem muttasıl hem de munkatı' olarak rivayet etmiştir.

Eserinde Gaylân'ın rivayetine yer veren âlimlerden birisi de Beyhakî'dir (ö. 458/1066). Kendisi birçok eserinde bu rivayete yer vermiş ve genel olarak rivayeti sahih kabul etmiştir. Ayrıca Beyhakî rivayeti hem muttasıl hem de munkatı' olarak nakletmiştir. ${ }^{31}$ Beyhakî'nin söz konusu rivayetin hem Basralılar hem de Kufeliler tarafindan muttasıl olarak rivayet edildiğini söylemesi onun bu konudaki en önemli yorumudur. Nitekim kendisi Basra âlimlerinden İbn Arûbe, İbn Uleyye, Muhammed b. Ca'fer Yezîd b. Zurey' ve başkaları bu rivayeti muttasıl olarak rivayet ettiğini ve bunların Basra hafızlarından olduğunu belirtmiştir. Aynı şekilde Kûfe âlimlerinden Ebû Ubeyd, Yahyâ b. Saîd, Süfyân gibi âlimler bu rivayeti Ma'mer'den muttasıl olarak nakletmişlerdir. ${ }^{32}$ Ayrıca Horâsânlı âlimler de bu rivayeti Ma'mer'den muttasıl olarak rivayet etmiştir. ${ }^{33}$

Beyhakî' nin rivayet ettiği bazı nakillerde söz konusu rivayet Ma'mer b. Râşid yerine Serrâr b. Müceşşir tarafından rivayet edilmiştir. Beyhakî Serrâr b. Müceşşir’in sika bir

\footnotetext{
${ }^{27}$ Dârekutnî, Sünen, 4: 403.

${ }^{28}$ Ebû Ca'fer Ahmed b. Muhammed b. Selâme el-Ezdî el-Hacrî el-Misrî et-Tahâvî, Şerhu maânî'l-âsâr (Kahire: Âlemü'l-Kütüb, 1994), 3: 253.

${ }^{29}$ Dârekutnî'nin rivayet ettiği üçüncü, dördüncü, beşinci ve altıncı tarikleri için bkz. Dârekutnî, Sünen, 4: 404, 4: 406, 4: 406, 4: 408.

${ }^{30}$ Söz konusu râvi ile ilgili bkz. Beyhakî, el-Hilâfiyât beyne’l-imâmeyn eş-Şâfî̀ ve Ebî Hanîfe, 6: 100; Beyhakî, Ma 'rifetü's-sünen, 10: 137.

31 Beyhaki, es-Sünenü'l-kübrâ, nşr. Muhammed Abdulkadir Atâ (Beyrut: Dâru'l-Kütübi'l-i̇lmiyye, 2003),

7: 241-294-295-296-297; Beyhakî, Ma 'rifetü's-sünen, 10: 136-137-138-139.

${ }^{32}$ Beyhakî, Ma'rifetü's-sünen, 10: 136. Ayrıca bkz. Beyhakî, es-Sünenü'l-kübrâ, 7: 295.

${ }^{33}$ Beyhakî'nin verdiği bilgilere göre Horâsânlı olan Ebû'l-Fadl b. Mûsâ es-Sînânî de bu rivayeti müttasıl olarak Ma 'mer'den nakletmiştir. Bkz. Beyhakî, es-Sünenü'l-kübrâ, 7: 295.
} 
râvi olduğunu da vurgulamıştır. ${ }^{34}$ Ayrıca Beyhakî’nin rivayetle ilgili naklettiği bir tarikte de ne Ma'mer ne Zührî ne de sahabi râvisi Abdullah b. Ömer yer almaktadır. Söz konusu rivayet Abdullah b. Abbâs tarafından nakledilmiştir. ${ }^{35}$ Bunun da Zührî ve Ma'mer bağlamında rivayetle ilgili var olan tartışmaları zayıf kılan bir unsur olduğu düşünülebilir. Zira tartışmaların genellikle Ma'mer ve bazılarının da Zührî ile ilgili olduğunu daha önce ifade etmiştik.

İbn Hacer de Telhị̂̂ü'l-Habîr fî Tahrîci Ehâdîsi'r-Râfi 'iyyi'l-Kebîr ve Muvâfakatü'lHubri'l-Haber fî Tahrîci Ehâdîși'l-Muhtașar adlı eserlerinde Gaylân b. Seleme rivayetine değinip geniş malumat vermiştir. Ayrıca tespit edebildiğimiz kadarıyla Gaylân b. Seleme rivayetiyle ilgili kanaat değiştiren sadece İbn Hacer'dir. Biz de her iki eserindeki görüşlerini detaylı bir şeklide verip onun düşüncesini belirlemeye çalışacağız. İbn Hacer Telhîsü'l-Habîr adlı eserinde rivayetin İmam Şâfîi, İbn Hibbân, Tirmizî ve İbn Mâce tarafından rivayet edildiğini söylemiştir. Ayrıca rivayetle ilgili var olan tartışmalara da değinmiş, özellikle Buhârî, Ebû Zür'a ve Ebû Hâtim'in söz konusu rivayetin illetli olduğunu belirttiklerini vurgulamıştır. Aynı şekilde İbn Hacer, Müslim'in; "Eğer bu rivayeti Basra'nın dışından güvenilir bir kişi Ma'mer'den nakletmişse onun sıhhatine hükmederiz.” görüşü bağlamında şu değerlendirmelerde bulunmuştur:

"İbn Hibbân, Hâkim ve Beyhakî bu hükmün zahirine göre hareket edip bu rivayeti Kûfe, Horâsân ve Yemâme halkı Ma'mer'den rivayet ettiklerini söylemişlerdir. Bütün bunların Mamer'den rivayette bulunmalarının hiçbir anlamı yoktur. Zira bunlar her ne kadar Basralı olmasalar da bu rivayeti Basra'da Ma'mer'den işitmişlerdir. Ayrıca eğer yukarıda geçen beldelerin râvileri bu rivayeti Basra'nın dışında Ma'mer'den nakletmişlerse de buna dayanarak rivayet sahih kabul edilmemelidir. Zira Ma'mer'in, beldesinin dışında rivayet ettiği hadisler genel olarak problemlidir. Çünkü Ma'mer, beldesinde kitaplarından rivayet ederdi ve bu rivayetler sahih kabul edilirdi. Ancak beldesinin dişına çıktığında ezberinden rivayette bulunurdu ve bu rivayetlerinde vehm ettiği söylenmektedir. Nitekim Ali b. Medînî, Buhârî Ebû Hâtim, Ya'kûb b. Şeybe ve başka âlimler de bu gerçeği dile getirmişlerdir." 36

İbn Hacer'in bu ifadeleri tahkik edildiğinde kendisiyle çeliştiği görülecektir. Zira ona göre Ma'mer Basra' da kendi kitaplarından rivayette bulunduğu için onun hadisleri sahih kabul edilmiştir. Ancak Ma'mer, Basra'nın dışına çıktığında ezberinden hadis rivayet ettiği için vehme düşmüştür. İbn Hacer'in bu tespitine göre Basra' da Ma'mer'den rivayet edilen bu hadis sahih kabul edilmelidir. Ayrıca onun bu yaklaşımı Müslim'in görüşüne de ters düşmektedir.

İbn Hacer Muvâfakatü'l-Hubri'l-Haber adlı eserinde ise söz konusu rivayete değinmiş ve Telhîșü'l-Habîr adlı eserindeki görüşüne muhalif bir kanaat ortaya koymuştur. Zira İbn Hacer Muvâfakatü'l-Hubri'l-Haber adlı eserinde bu rivayetin hasen olduğunu; Ahmed b. Hanbel Yezîd b. Hârûn'dan nakletmiş; dolayısıyla rivayetin âlî bir isnadla

\footnotetext{
${ }^{34}$ Beyhakî, Ma 'rifetü's-Sünen, 10: 137.

${ }^{35}$ Beyhaki, es-Sünenü'l-kübrâ, 7: 297.

36 İbn Hacer, Telhîșü̈'l-habîr fî tahrîci ehâdîși'r-Râfi 'iyyi 'l-kebîr (Beyrut: Dâru'l-Kütübi'l-İlmiyye, 1989), 3: 367-368.
} 
geldiğini söylemiştir. Ayrıca İbn Hacer, Tirmizî bu rivayeti Abde b. Süleyman o da Saîd b. Arûbe'den rivayet etmiş, rivayetin bu senediyle de âlî olduğunu ifade etmiştir. ${ }^{37}$

İbn Hacer bu eserinde Nesâ̂’nin söz konusu rivayeti Ma'mer'in yer almadığı başka bir senedle rivayet ettiğini vurgulamıştır. Bu sened de Eyyüb es-Sahtiyânî - Sâlim ve Nâfi" - İbn Ömer şeklindedir. Görüldüğü gibi rivayetin bu senedinde tartışmaların odağında yer alan Ma'mer yer almamaktadır. İbn Hacer bu senedin bağlamında şöyle demiştir: "Bu da gösteriyor ki bu hadisin bir asl1 vardır." 38

İbn Hacer'in, Telhîsü'l-Habîr adlı eserinde söz konusu rivayetle ilgili ifadeleri tahkik edildiğinde kendisinin, Buhârî'nin bu rivayeti gayr-1 mahfuz olarak kabul ettiği yönündeki görüşüne ihtiyatla yaklaştığını söylemek mümkündür. ${ }^{39}$ Çünkü İbn Hacer'in, Buhârî'nin bu görüşünü doğrudan Buhârî'den nakletmediği, bilakis Tirmizî'ye nispet ettiği görülmektedir. Ancak Buhârî'nin; Zührî - Sâlim - Abdullah b. Ömer'den nakledilen rivayetin; "Sakîf kabilesinden bir adam eşlerini boşadı, Hz. Ömer ona eşlerini döndürmesini, aksi takdirde onu recm edeceğini söyledi" şeklinde olduğunu söylemiştir. İbn Hacer Buhârî'nin bu görüşünü: "Buhârî dedi” diyerek doğrudan ona nispet etmiştir. ${ }^{40}$ İbn Hacer aynı tereddüdü Muvâfakatü'l-Hubri'l-Haber adlı eserinde de dile getirmiştir. Ona göre Buhârî, Zührî'nin rivayetinin senedinde ihtilaf edildiği için bu hadisin muallel olduğunu söylemiştir. ${ }^{41}$

İbn Hacer Telhîsü'l-Habîr adlı eserinde söz konusu rivayetin muallel olduğunu ve Ma'mer b. Râşid'in rivayeti muttasıl olarak nakletmede vehme düştügünü belirtmiştir. Ancak Muvâfakatü'l-Hubri'l-Haber adlı eserinde ise bir önceki görüşünün aksine bir yaklaşım sergilemiş ve rivayetin âlî bir isnadla gelip illetten beri olduğunu ifade etmiştir. Şüphesiz bu gibi durumlarda müelliflerin en son yazdığı kitap dikkate alınmalı ve son kitapta yer alan görüş genel olarak daha güvenilir kabul edilmelidir diye düşünüyoruz. Zira herhangi bir müellifin nihai görüşlerinin son yazılan eserinde yer alması kuvvetle muhtemeldir. Bu bağlamda İbn Hacer'in meşhur talebesi Sehâvî'ye göre İbn Hacer Muvâfakatü'l-Hubri'l-Haber adlı eseri Telhîsü'l-Habîr'den sonra yazmıştır. Zira kaynaklarda geçtiği üzere İbn Hacer hicri 812 tarihinde Telhîsü'l-Habîr adlı eserini yazmaya başlamış ve 820 'de de bu eserini bitirmiştir. ${ }^{42}$ Muvâfakatü'lHubri'l-Haber adlı eserini ise 830 tarihinde yazmıştır ${ }^{43}$. Görüldüğü gibi her iki eser arasında on yıl vardır. Dolayısıyla İbn Hacer'in, Muvâfakatü'l-Hubri'l-Haber adlı eserindeki görüşünün yani söz konusu rivayetin sahih olduğu fikrinin dikkate alınması uygundur. Bu bakımdan İbn Hacer'in de bu rivayeti sahih olarak kabul eden âlimler arasında kabul edilmesinin daha doğru olacağını düşünüyoruz.

\subsection{Gaylân b. Seleme Rivayetini Sahih Kabul Etmeyen Âlimler}

\footnotetext{
37 İbn Hacer, Muvâfakatü'l-hubri'l-haber fì tahrîci ehâdîși'l-Muhntaṣar (Riyad: Mektebetü'r-Rüşd, Riyâd 1993), 1: 79.

38 İbn Hacer, Muvâfakatü'l-hubri'l-haber fì tahrîci ehâdîsíl'l-Muhtașar, 1: 79.

39 Bilindiği gibi ibn Hacer birçok meselede Buhârî’yi savunmuş ve bu bağlamda eserler telif etmiştir. Konuyla ilgili geniş bilgi için bkz. Mehmet Bilen, İbn Hacer'in Buhârî Savunusu (Ankara: Ankara Okulu, 2013).

40 İbn Hacer, Telhîșü'l-ḥabîr fi tahrîci ehâdîsisi'r-Râfi 'iyyi l-kebîr, 3: 368.

${ }^{41}$ İbn Hacer, Muvấfakatü'l-hubri'l-haber fí tahrîci ehâdî́si'l-Muhtașar, 1: 79.

42 İbn Hacer, Telhîșü̉ l-habîr fi tahrîci ehâdîsisi'r-Râfi 'iyyi'l-kebîr, 4: 404.

${ }^{43}$ Ebü'l-Hayr Şemsüddîn Muhammed b. Abdirrahmân b. Muhammed es-Sehâvî, el-Cevâhir ve'd-dürer fî tercemeti Şeyhi'l-İslâm İbn Hacer (Lübnan: Dâru İbn Hazm 1999), 2: 582.
} 
Gaylân b. Seleme rivayetini sahih kabul etmeyenlerin başında Buhârî gelmektedir (ö. 256/870). Ona göre Gaylân b. Seleme ile ilgili rivayetlerin en sahihi şu senedle gelen nakildir: Abdullah b. Sâlih ve İbn Bukeyr - Leys- Ukayl - Zürî: Bize, Osman b. Muhammed'den ulaştığına göre Gaylân b. Seleme Müslüman olduğunda on kadınla evliydi. Bunun üzerine Hz. Peygamber (s.a.s) kendisine şöyle dedi: "Onlardan (hanımlarından) dördünü al, diğerlerini boşa." ${ }^{44}$ Buhârî'nin tarikler arasında en sahihi olarak kabul ettiği bu senedde iki problem söz konusudur. Birincisi; Zührî ile Osman b. Muhammed arasında bir kopukluk olduğu anlaşılmaktadır. Zira Zührî her ne kadar Osman b. Muhammed'e yetişmişse de bu rivayeti doğrudan ondan işitmediğini ifade eden (بلغنا/Bize ulaştı) ifadesini kullanmıştır. Eğer Zührî söz konusu rivayeti bizzat Osman b. Muhammed'den almış olsaydı (بلغنا/Bize ulaştı) ifadesi yerine (سمعت//ş̧ittim) gibi doğrudan ondan aldığını belirten bir ifade kullanacaktı. Zira hadis âlimleri genel olarak (بلغنا، بلغني) ifadelerle nakledilen rivayetleri munkatı‘ olarak kabul etmişlerdir. ${ }^{45}$ İkinci problem ise rivayetin mürsel olmasıdır. Zira Buhârî'nin nakline göre tâbiî olan Osman b. Muhammed, bu rivayeti doğrudan Hz. Peygamber'den nakletmiştir. Buhârî, bu iki nedenden olsa gerektir ki, bu rivayeti gayr-1 mahfuz ve muallel olarak kabul etmiştir. Ayrıca Buhârî, Zührî’nin söz konusu rivayeti mürsel olarak rivayet ettiğini gösteren nakle de yer vermiştir. ${ }^{46}$

Tirmizî, Buhârî'nin söz konusu rivayetle ilgili kanaatini şöyle belirtmiştir: "Buhârî̀ye göre rivâyetin bu senedi mahfûz değildir ve Zührî, söz konusu rivayeti Sâlim'den değil, Osman b. Muhammed b. Süveyd'den almıştır." Ayrıca Buhârî̀ye göre Zührî’nin Sâlim'den, onun da babası Abdullah b. Ömer'den naklettiği rivayet, Gaylân'ın, Hz. Ömer'in hilafeti döneminde hanımlarını boşadığını ve mallarını çocuklarına dağıttığını belirten rivayettir. ${ }^{47}$ Aynı şekilde Buhârî et-Târîhu'l-Evsat, adlı eserinde: "Bu konuda Hz. Peygamber'den her hangi bir rivayet sabit değildir" 48 diyerek kanaatini ifade etmiştir. Tahâvî de (ö. 321/933) Gaylân b. Seleme rivayetini sened açısından munkatı“ kabul etmiş ve söz konusu rivayetin herhangi bir meselede delil olamayacağını ifade etmiştir. ${ }^{49}$

İbn Ebî Hâtim (ö. 327/938) el-illel adlı eserinde söz konusu rivayete yer vermiş ve Ebû Zür'â'nın (ö. 264/878), rivayetini mürsel olarak kabul etmenin daha doğru olacağını söylediğini aktarmıştır. ${ }^{50}$ Ayrıca İbn Ebî Hâtim, söz konusu rivayetin muttasıl geldiğini ifade eden senedinin durumunu babası Ebû Hâtim'e (ö. 277/890) sormuş, babası muttasıl olduğunu gösteren senedde bir yanılma söz konusu olduğunu söylemiş ve Gaylân b. Seleme ile ilgili rivayetin mürsel olduğunu ifade etmiştir. ${ }^{51}$

\subsection{Rivayet Tartışmalarının Odağında Yer Alan Ma'mer b. Râşid}

\footnotetext{
44 Ebû Abdillâh Muhammed b. İsmâîl b. İbrâhîm el-Cu'fî̀ el-Buhârî et-Târîhu'l-kebîr, nşr. Mustafa Abdulkadir Ahmed Atâ, 2. Bask1 (Beyrut: Dâru'l-Kütübi’l-İlmiyye, 2008), 6: 86.

45 İbnü's-Salâh, Ma'rifetu ulûmi’l-hadîs, 94. Zührî, mürsel olarak olarak rivayet ettiği birçok rivayette (بلغنا) ifadesini kullanmıştır. Birkaç örnek için bkz., Buhârî, et-Târîhu'l-evsat, 2: 1106; Dârekutnî, elİlelü'l-varide fi'l-ehâdîsi'n-nebeviyye (Beyrut: Müessesetür'r-Reyyân, 2011), 4:4-445, 6:174, 9:151. İmâm Mâlik'in (بلغنا، بلغني) ifadeleriyle rivayet ettiği hadisleri el-Muvatta"nin dişında muttasıl olarak rivayet ettiği söylenmiştir. Bkz., Ebü'l-Fazl Zeynüddin Abdürrahim b. Hüseyin Irakî, et-Takyid ve'l-izah şerhu mukaddimeti İbni's-Salah, 5. Baskı (Beyrut: Müessesetü'l-Kütübi's-Sakâfiyye 1997), 82.

${ }^{46}$ Buhârî, et-Târîhu'l-kebîr, 6: 87.

47 Tirmizî, "Nikâh", 33.

${ }^{48}$ Buhârî, et-Târîhu'l-evsat, nşr. Teysîr b. Sa ‘d (Riyâd: Dâru'r-Rüşd, 2005), 3: 210.

49 Tahâvî, Şerhu maânî̀l-âsâr, 3: 252.

50 İbn Ebî Hâtim, el-İlel, nşr. Ebû Ali en-Nazîf (Beyrut: Dâru'l-Kütübi'l-İlmiyye, 2006), 1: 351.

51 İbn Ebî Hâtim, el-illel, 1: 352.
} 
Gaylân b. Seleme rivayeti ile ilgili yapılan tenkitlerin çoğunun Ma'mer b. Râşid (ö. 153/770) ile ilgili olduğu görülmektedir. Zira yukarıda geçtiği üzere Buhârî ve Tahâvî aslında munkatı' olan bu rivayeti Ma'mer' in vehm ederek muttasıl olarak rivayet ettiğini belirtmişlerdir. Aynı şekilde Ebû Zür'â ve Ebû Hâtim'e göre de bu rivayet mualleldir, bu illetin sebebi de Ma'mer b. Râşid'dir. Ayrıca İbn Hacer'e göre de onun Basra dışındaki rivayetleri muzdaribtir ve bu hususta İbnü'l-Medînî, Buhârî, Ebû Hâtim ve Ya'kûb b. Şeybe gibi hadis münekkitlerinin ittifakı söz konusudur. ${ }^{52}$ Bundan dolay1 biz de Ma'mer b. Râşid'in hayatını özet bir șekilde vermek suretiyle bu rivayet ile ilgili söylenen iddiaların sıhhatini ortaya koymaya çalışacağız.

Zehebî'ye Ma'mer b. Râşid 95 (714) veya 96 (715) yılında Basra'da dünyaya gelmiş, küçük yaşta ilim tahsiline başlamış ve Hasan-1 Basrî’nin (ö. 110/728) cenazesinde de hazır bulunmuştur. ${ }^{53}$ Hadis münekkitleri genel olarak Ma'mer'i sika ve güvenilir olarak kabul etmişlerdir. Mesela kaynaklarda genellikle isnadın Hicâz'da Zührî ve Amr b. Dînâr, Kûfe'de Ebû İshâk ve A'meş, Basra' da Katâde ve Yemâme'de Yahyâ b. Kesîr'e dayandırılmıştır. Ma'mer de mezkur âlimlerden ilim öğrenmiş ve Ebû Hâtim'e göre Ma'mer'in dışında hiç kimse bu firsata sahip olamamıştır. ${ }^{54}$ Aynı şekilde Ma'mer'in ilim için Yemen'e yolculuk yaptığı belirtilmekte, araştırmacı ve iyi tasnif sahibi olmakla beraber ilmin kaynağı olarak da bilinmektedir. Zira yukarıda değinildiği gibi Ma'mer isnadın merkezinde yer alan âlimlerin tamamına yetişmiş ve onlardan hadis almıştır. Ayrıca Ma'mer, Zührî’nin rivayetlerini en iyi bilen kişi olarak da kabul edilmektedir. ${ }^{55}$

Tabakât kitaplarında Ma'mer ile ilgili bazı tenkitler de yapılmıştır. Mesela Ebû Hâtim, Ma'mer'in Basra'daki rivayetlerinde hata yaptığına işaret etmiş, bununla beraber onu ta"dîl lafızlarından olan "Sâlihü'l-hadîs" 56 tabiriyle nitelemiştir. ${ }^{57}$ Aynı şekilde Müslim de Ma'mer'in, Basra'da vehm ettiğini söylemiştir. ${ }^{58}$ Ayrıca Mâlik, Ma'mer'in tefsir ile ilgili Katâde'den naklettiği rivayetleri hoş karşılamamıştır. ${ }^{59}$

Ma'mer b. Râşid ile ilgili yapılan en büyük tenkit İbn Hacer'in yukarıda geçen iddiasıdır. Zira o iddiaya göre Ma'mer'in, kitabın dışında rivayet ettiği bütün hadisler sorunludur. Hâlbuki Hişâm b. Yûsuf"un şöyle dediği de nakledilmektedir: "Ma'mer bizim yanımızda yirmi yıl kaldı, biz onun hiçbir kitabını görmedik." Zehebî, Hişâm b. Yûsuf'un bu sözünü, "Yani onlara ezberinden hadis rivayet ediyordu." şeklinde açıklamıştır. Dolayısıyla İbn Hacer'in delil sunmadan dile getirdiği bu iddianın tenkide açık bir yaklaşım olduğu söylenebilir. Ayrıca yukarıda da ifade edildiği gibi İbn Hacer'e göre Ali b. Medînî, Buhârî ve Ebû Hâtim gibi hadis münekkitleri, Ma'mer b. Râşid'in, memleketinden çıktığı zaman hafızasından rivayet etmiş ve birçok defa vehme düştüğünü söylemişlerdir. Tespit edebildiğimiz kadarıyla bu iddia sadece İbn Hacer

\footnotetext{
52 İbn Hacer, Telhị̂̂ü'l-ḥabîr fi tahrîci ehâdîși’r-Râfi 'iyyi'l-kebîr, 3: 367.

53 Ebû Abdillâh Şemsüddîn Muhammed b. Ahmed b. Osmân ez-Zehebî et-Türkmânî el-Fârikī, Siyeru a'lâmi'n-nübelâ (Kahire: Dâru'l-Hadîs 2006), 6: 471.

54 İbn Ebî Hâtim, el-Cerh ve't-ta 'dîl, 8: 293.

55 Mizzî, Tehzîbü'l-Kemâl fî esmâi'r-ricâl, 28: 307 vd.; Zehebî, Siyeru a'lâmi'n-nübelâ, 6: 472; İbn Hacer, Tehzîbü't-Tehzîb, 10: 219.

56 İbn Ebî Hâtim'e göre bu tabir ta 'dîlin üçüncü mertebesinde yer almakta ve bu ifadeyle nitelenen râvini rivayeti i 'tibar için yazllabilmektedir. İbn Ebî Hâtim, el-Cerh ve't-ta 'dîl, 1: 324.

${ }^{57}$ İbn Ebî Hâtim, el-Cerh ve 't-ta 'dîl, 8: 293-294.

${ }^{58}$ Bkz. İbn Hacer, Telhîșü'l-habîr fì tahrîci ehâdî̀si 'r-Râfi 'iyyi'l-kebîr, 3: 368.

59 Zehebî, Siyeru a'lâmi'n-nübelâ, 6: 474.
} 
tarafından dile getirilmiş ve İbn Hacer Telhîsü'l-Habîr adlı eserinde bu iddiasını herhangi bir delille temellendirmemiştir.

Ma'mer b. Râşid ile ilgili dikkat edilmesi gereken bir husus da kendisinin, Zührî'den rivayette bulunanlar içerisinde en güvenilir kişilerden biri olmasıdır. Bu yaklaşım başta İbn Hacer olmak üzere diğer âlimler tarafından da dile getirilmiştir. ${ }^{60} \mathrm{Bu}$ bağlamda yukarıdaki açıklamalar göz önünde bulundurulduğunda Ma'mer'in, Basra'da rivayet ettiği bazı hadislerde hata yaptığını düşünülebilir. Ancak bunu genelleştirip Basra'daki bütün rivayetlerine teşmil etmek doğru bir yaklaşım olmayacaktır. Ayrıca İbn Maîn'in şu ifadesi de konumuz açısından önemlidir: "Ma'mer sana Iraklılardan hadis rivayet ettiğinde ona muhalefet et, Zührî ve İbn Tâvus hariç. Zira Ma'mer'in onlardan rivayet ettiği hadisleri doğrudur. Aynı şekilde Ma'mer'in, Sâbit, Âsım b. Ebî'n-Nücûd ve Hişâm b. Urve'den rivayetleri de muzdaribtir ve çok hatalıdır." ${ }^{\prime \prime} \mathrm{Bu}$ açıdan bakıldığında çalışmamıza konu olan Gaylân b. Seleme rivayetinin sahih olduğu söylenebilir. Zira bu rivayeti Ma'mer, Zührî’den nakletmiştir. Ayrıca Müslim'in iddiasına göre eğer Basralıların dışında herhangi sika birisi bu rivayeti Ma'mer'den nakletmişse rivayet yine sahih kabul edilmelidir. Görüldüğü gibi bu rivayeti Basralıların dışında da Ma'mer'den rivayet edenler vardır.

Tabakât kitaplarında yer aldığına göre Ma'mer b. Râşid, annesini ziyaret etmek amaciyla Basra'ya gitmiş ve burada bir takım rivayetlerde bulunmuştur. ${ }^{62}$ Ma'mer bu ziyareti esnasında hadis rivayet ederken kitaptan değil, ezberden aktarım yaptığı ve bazı rivayetlerde hata ettiği söylenmiştir. İşte, Ma'mer'in Basra'daki rivayetlerine yapılan tenkidin temel nedeninin bu olduğunu düşünüyoruz. Zira tespit edebildiğimiz kadarıyla Basra'daki rivayetleri dişında Ma'mer'e ciddi bir tenkit yönetilmemiştir. Bu bağlamda bazı münekkitler bundan hareketle "Ezberinde rivayet ettiğinde hata yapmış, kitaptan rivayet ettiğinde ise doğru nakletmiş." gibi genel bir sonuca gitmişlerdir. Ancak Ma'mer'i bu konuda tenkit edenler iddialarını güçlendirecek herhangi bir rivayete başvurmamışlardır. Bundan dolayı Ma'mer'e yöneltilen tenkitlerin sahihliği pratik ve örnekler üzerinde test edilmediği için böyle bir iddayı genelleştirmenin pek de makbul görünmemektedir.

Buhârî ve Tahâvî'nin iddiasına göre Gaylân b. Seleme ile ilgili iki rivayet vardır. Birincisi çalışmamıza konu olan rivayet, ikincisi ise Gaylân'ın Hz. Ömer' in hilafeti döneminde hanımlarını boşaması olayıdır. Her iki rivayetin senedinde de Zührî ve Ma'mer yer almaktadır. Buhârî ve Tahâvî'ye göre birinci haber munkatı', ikinci rivayet ise muttasıldır. Ancak Ma'mer, vehm ederek birinci rivayeti de muttasıl şeklinde nakletmiştir. Buhârî ve Tahâvî'nin bu yaklaşımları da tenkide açıktır. Zira elimizde bunu ortaya koyacak net bir delil yoktur. Ayrıca Ma'mer her iki rivayeti de muttasil şeklinde nakletmiş olabilir. Bununla beraber yukarıda değinildiği üzere Nesâî ve Dârekutnî başta olmak üzere bazı âlimlerin nakline göre çalışmamıza konu olan hadis Ma'mer ve Zührî'nin yer almadığı başka muttasıl senedlerle de rivayet edilmiştir. Bunun da Buhârî ve Tahâvî’nin görüşlerinin zayıf kıldığını ve bu hadisin sıhhatini güçlendirdiğini düşünüyoruz.

\section{GAYLÂN B. SELEME RIVAYETİ BAĞLAMINDA VAR OLAN FIKHÎ İHTILAFLAR}

\footnotetext{
${ }^{60}$ Bkz. Mizzî, Tehzîbü'l-Kemâl fì esmâi'r-ricâl, 28: 308.

${ }^{61}$ İbn Hacer, Tehzîbü't-Tehzîb, 10: 219.

${ }^{62}$ Zehebî, Siyeru a'lâmi’n-nübelâ, 6: 473.
} 
Mezhep imamları başta olmak üzere âlimler arasında var olan ihtilafların temel nedenlerinden birisi de rivayetlere farklı yaklaşımlarıdır. ${ }^{63}$ Başka bir ifade ile bir âlimin sahih kabul ettiği bir rivayeti başka bir âlim sahih görmeyebilir. Zira hadisleri sahih kabul etme kriterleri farklı olduğu için aynı rivayet hakkında farklı sonuçlara varılabilmektedir. Ayrıca bazen râviler de farklı sonuçların ortaya çıkmasına sebep olabilmektedir. Mesela râviler bazen bir hadisin tamamını aktaramamışlar veya rivayet esnasında hata yapmışlar; bunlara bağlı olarak aynı hadis farklı varyantlarla rivayet edilmiş, böylece lafız ve anlam bakımından farklılıklar ortaya çıkmıştır. ${ }^{64}$

Müslüman olmadan önce dörtten fazla kadınla evli olan kişinin durumu ile ilgili birbiriyle çelişen iki farklı görüş öne sürülmüştür. Birinci görüşe göre, bu durumda olan bir kişinin, hanımlarından istediği dördünü yanında tutacak, diğerlerini ise zorunlu olarak boşayacaktır. İkinci görüşe göre ise, Müslüman olmadan önce kıyılan nikâha göre hüküm verilecektir. Buna göre eğer birden fazla kadının nikâhı bir akitte kıyılmışsa bütün kadınların nikâhları geçersiz olur ve boş olurlar. Ancak kadınların nikâhları farklı akitlerde kıyılmışsa o zaman kişi ilk dört hanımını tercih etmek zorunda, diğerlerini ise boşaması gerekmektedir. İşte Gaylân b. Seleme rivayeti, dörtten fazla kadınla evli olanın durumuyla ilgili verilen fetvaların temellendirilmesinde önemli rol oynamıştır. Zira hadis münekkitleri söz konusu rivayeti kabul etmede ihtilaf etmişlerdir. Bazı âlimler rivayeti munkatı" ve mürsel olduğu için muallel kabul etmiş ve kendisiyle amel edilemeyeceğini söylemişler, bazı âlimler de rivayetin muttasıl olduğunu söyleyip onunla amel etmişlerdir.

İmam Şâfiî (ö. 204/820) ve Ebû Hanife'nin talebesi olan İmam Muhammed b. Hasan eşŞeybânî (ö. 189/805) başta olmak üzere bazı âlimler söz konusu meselede nikâhın bir akit veya farklı akitlerde kılınmasının ayırımını yapmamışlardır. Onlara göre Müslüman olmadan önce dörtten fazla kadınla evlenen bir kişi İslam'ı kabul ettikten sonra dilediği hanımlarından dördünü yanında tutar, diğerlerini de boşar. ${ }^{65}$ Başta İmam Şâfiî olmak üzere bu görüşü savunan âlimlerin başvurduğu naklî delillerin başında Gaylân b. Seleme rivayeti gelmekte ve bu âlimler görüşlerini onunla temellendirmektedirler. Onlara göre Gaylân'ın rivayeti muttasıl olup sahihtir ve ona göre hüküm verilmelidir.

İbn Abdilber ise (ö. 463/1071) söz konusu rivayetin hem muttasıl hem de mürsel varyantlarına yer verdikten sonra kendi kanaatini şöyle belirtmiştir. "Bu konuda rivayet edilen bütün hadisler illetli olup senedleri güçlü değildir. Ancak bu rivayetlere muhalif herhangi bir şey de Hz. Peygamber'den (s.a.s.) nakl edilmemiştir. Dolayısıyla bunlarla amel etmek evladır, Allahu a'lem."

Birinci görüşü savunan Hanbelî âlim İbn Kudâme (ö. 620/1223) görüşünü Kays b. Hâris'in şu rivayetiyle de pekiştirmiştir: "Müslüman olduğumda sekiz kadınla evliydim, Hz. Peygamber'in yanına geldiğimde bana dördünü tercih etmemi söyledi.” Ayrıca İbn

\footnotetext{
63 İslam ulemasına göre naslar arasında herhangi bir zıtlığın bulunması mümkün değildir. Ancak bu nasları yorumlayanların bakışları arasında zıtlık veya farklılık olabilmektedir. Nitekim İmam Şâfîî, Hatîb Bağdâdî ve Şâtıbî bu gerçeğe işaret etmişlerdir. Konuyla ilgili geniş bilgi için bkz. Şâfîi, er-Risâle, 280; Bağdâdî, el-Kifâye fî ilmi'r-rivaye, 371; İbrahim b. Musa eş-Şâtıbî, el-Muvâfakât, (Kâhire: Dâru İbn Affân, 1997), 7: 78.

${ }^{64}$ Süleyman Doğanay, Râvi Tasarruflarının Doğurduğu Problemler (İstanbul: İSAM, Yayınları, 2009) 160.

${ }^{65}$ Şâfîi, el-Ümm, 4: 281; Tahâvî, Şerhu maânî̀l-âsâr, 3: 252.

${ }^{66}$ Ebû Ömer Cemâlüddîn Yûsuf b. Abdillâh b. Muhammed b. Abdilber en-Nemerî, et-Temhîd, nşr. Mustafa b. Ahmed - Muhammed b. Abdülbekîr (Mağrib: Vizâretu Umûm’il-Evkâf, 1387), 12: 58.
} 
Kudâme, kendisinin de savunduğu birinci görüşü Mâlik, Leys, Evzâî, Sevrî, Şâfiî, İshâk ve Muhammed b. Hasan ve Ahmed b. Hanbel'e de nispet etmiştir. ${ }^{67}$

İkinci görüşü savunan âlimler ise Gaylân b. Seleme rivayetini muallel kabul etmiş ve bu rivayete dayanarak herhangi bir istinbatta bulunulamayacağını söylemişlerdir. İmam Ebû Hanife (ö. 150/767), Ebû Yusuf (ö. 182/798) ve Tahâvî (ö. 321/933) ikinci görüşü savunanlardandir. Nitekim Tahâvî söz konusu rivayeti Müslüman olmadan önce dörtten fazla kadınla evli olan kişinin durumu bağlamında ele almıştır. Onun verdiği bilgiler göz önünde bulundurulduğunda söz konusu rivayetle ilgili var olan tartışmanın temelinde âlimlerin fikhî görüşlerinin yer aldığı söylenebilir. Zira Müslüman olmadan önce dörtten fazla kadınla evli olan bir kişinin, Müslüman olduktan sonra dörtten fazla hanımını boşaması ile ilgili ihtilaf söz konusudur. İmam Ebû Hanife (ö. 150/767) ve Ebû Yusuf'a (ö. 182/798) göre eğer kişi Müslüman olmadan önce bir akitle dörtten fazla kadınla evlenmişse onun nikâhı geçersiz olur ve bütün hanımları ondan boş olur. Ancak kişi dörtten fazla evliliğini farklı akitlerde yapmışsa Müslüman olduktan sonra ilk dört hanımının nikâhları geçerli, diğerleri ise geçersiz olur ve onları boşaması gerekir. Bu görüşü savunanlar, Gaylân b. Seleme ile ilgili rivayetin muttasıl olmadı̆̆ını, onun için delil olmayacağını belirtmişlerdir. Nitekim Tahâvî, üç munkatı' senedle İbn Şihâb Zührî'nin şöyle dediğini nakletmiştir: "Bize ulaştığına göre Hz. Peygamber (s.a.s.) Müslüman olan ve dörtten fazla kadınla evli olan Sakif kabilesine mensup bir adama, 'Hanımlarından dördünü yanında tut, diğerlerini ise boşa' demiştir."'68

Tahâvi'nin iddiasına göre Zührî, Gaylân b. Seleme rivayetini Sâlim'den, o da babası Abdullah b. Ömer'den değil, tâbiî olan Osman b. Muhammed b. Ebî Süveyd'den nakletmiştir. Osman b. Muhammed de hadisleri mürsel olarak rivayet etmesiyle bilinmektedir. Nitekim İbn Ebî Hâtim el-Cerh ve't-Ta'dîl adlı eserinde bu duruma işaret etmektedir. ${ }^{69}$ Bundan dolayı Tahâvî, rivayetin sened açısından fasit olduğunu belirtmektedir. Zira ona göre eğer Zührî bu rivayeti Sâlim b. Abdullah'tan duymuş olsayd1, Osman b. Muhammed b. Ebî Süveyd'den değil, doğrudan Sâlim'den naklederdi. Aynı şekilde Tahâvî'ye göre Ma'mer b. Râşid, Zührî'nin bu rivayeti doğrudan Sâlim'den işittiği konusunda yanılmıştır. Zira Ma'mer b. Râşid, Gaylân b. Seleme ile ilgili iki rivayeti Zührî'den nakletmiştir. Birincisi yukarıda geçen rivayettir. İkincisi ise Gaylân'ın eşlerini boşaması ve malını da taksim etmesi ile ilgili rivayettir. Tahâvî'nin iddiasına göre Zührî, bu ikinci rivayeti Sâlim'den o da babası Abdullah b. Ömer'den nakletmiştir. Ancak Ma'mer, Hz. Peygamber'in sözü olan birinci rivayeti, Hz. Ömer'e nispet edilen ikinci rivayetin senediyle rivayet ederek hata etmiştir. ${ }^{70}$

Bazı Hanefi âlimlere göre Gaylân b. Seleme rivayeti sahih kabul edilse bile delil olmaya uygun değildir. Zira Gaylân'ın evliliği cahiliye dönemindeydi ve o dönemde de bu sayıdaki evlilik caizdi. İslam geldikten sonra çok evlilik dörtle sınırlandırıldı. ${ }^{71}$ Serahsî ise (ö. 483/1090) konuyla ilgili Mekhûl'den şöyle bir nakil aktarmıştır: "Hz. Peygamber'in; 'Hanımlarından dördünü yanında tut' sözü, nikâh akdinin yenilenmesine

\footnotetext{
67 Ebû Muhammed Muvaffakuddîn Abdullah b. Ahmed b. Muhammed b. Kudâme el-Cemmâîlî elMakdisî, Muğnî, (Beyrut: Dâru İhyâi’t-Turâsi'l-Arabî, 1985), 7: 120-121. İbn Kudâme'nin, hadis hafızlarının Gaylân b. Seleme'nin rivayetinin mürsel ve gayrı mahfuz olduğunu da ifade etmiştir. Bundan olsa gerektir ki, kendisi, görüşünü Kays b. Hâris’in rivayetiyle güçlendirme ihtiyacını hissetmiştir.

${ }^{68}$ Geniş bilgi için bkz. Tahâvî, Şerhu maânî'l-âsâr, 3: 252.

${ }^{69}$ Bkz. İbn Ebî Hâtim, el-Cerh ve’Ta 'dîl, 6: 165.

${ }^{70}$ Tahâvî, Şerhu maânî̀l-âsâr, 3: 253-254.

71 Cemâlüddîn Ebû Muhammed Ali b. Ebî Yahyâ el-Menbecî, el-Lübâb fì'l-cem'i beyne 's-sünne ve'lKitâb, (Dımeşk: Dâru'l-Kalem, 1994), 2: 675.
} 
işaret etmektedir. ${ }^{72}$ Serahsî’nin naklettiği bu görüş Kudûrî (ö. 428/1037) tarafindan da dile getirilmiş ve benimsenmiştir. ${ }^{73}$ Yani bu yoruma göre dörtten fazla kadınla evli olan bir kişi, Müslüman olduktan sonra hanımlarından dördünü yeni bir nikâhla yanında tutar, diğerlerini ise boşamak zorundadır. Ancak bazı âlimler tarafından dile getirilen bu yaklaşımın tenkide açık bir görüş olduğu söylenebilir. Zira daha önce geçtiği üzere İmam Ebû Hanife ve Ebû Yusuf'a göre dörtten fazla kadınla evli olan birisi, eğer hanımlarını bir akitle nikâhlamışsa bütün hanımları boş olur. Ancak farklı akitlerle onlarla evlenmişse o zaman ilk dördünü yanında tutacak, diğerlerini ise boşayacaktır. Gaylân b. Seleme'nin, on hanımını bir akitle mi yoksa farklı akitlerle mi nikâhladığına dair elimizde herhangi bir bilgi yoktur. Dolayısıyla Hz. Peygamber'in ifadesini yeni bir nikâh akdine hamletmenin zorlama bir yorum olduğunu ifade etmek isteriz.

Hanefi âlimlerinden Cessâs (ö. 370/981) Şerhu Muhtasari't-Tahâvî adlı eserinde konuyla ilgili ulemanın görüşlerine yer vermiş, Ebû Hanife ve Ebû Yusuf'un görüşlerini destekleme sadedinde açıklamalarda bulunmuştur. Cessâs, İmam Ebû Hanfe ve Ebû Yusuf'un görüşlerini şu akli çıkarımla temellendirmiştir: Bir akdin başlangıcı İslam'da sahih değilse onun üzerinde devam etmek de caiz değildir. İki kız kardeşle veya beş kadınla evli olanın durumu da böyledir. Bu iki evlilik çeşidinin başlangıcı nasıl caiz olmuyorsa bir Müslümanın bunun üzerinde devam etmesi de mümkün değildir. ${ }^{74}$ Ayrıca Cessâs, İmam Şâfiî ve onun gibi düşünen âlimlerin Gaylân b. Seleme ve birkaç rivayeti delil olarak sunduğunu da ifade etmiştir. Ancak Cessâs'a göre Gaylân b. Seleme ile ilgili rivayet mürseldir ve delil olmaya uygun değildir. Ayrıca ona göre bu nakiller doğru olsa bile yine ihtilafa neden olamaz. Zira Hz. Peygamber'in sözünün yeni bir akde veya hanımlarından ilk dördünün seçimine delalet etme ihtimali söz konusudur. ${ }^{75}$

Gaylân b. Seleme rivayeti Hicaz ve Irak fakihlerin görüşlerini de etkilemiştir. Mesela Hicaz fakihleri, Gaylân b. Seleme rivayetine dayanarak dörtten fazla kadınla evli olan birisinin Müslüman olduktan sonra istediği hanımlarından dördünü yanında tutabileceğini, diğerlerini ise boşaması gerektiğini söylemişlerdir. Irak fukahası ise söz konusu rivayeti muttasıl olmadığ olan birisinin İslam'1 seçtikten sonra ilk dört hanımını yanında tutmasını ve diğerlerini boşaması gerektiğini ifade etmişlerdir. ${ }^{76}$

İbn Hazm ise (ö. 456/1064), Gaylân b. Seleme ile alakalı rivayeti, "Dörten fazla kadınla evlenme meselesi" başlığı altında ele almış ve söz konusu rivayeti delil getirerek dörtten fazla kadınla evlenmenin caiz olmadığını söylemiştir. Ayrıca İbn Hazm, Ma'mer b. Râşid'den dolayı Gaylân'ın rivayetine yapılan tenkitleri de kabul etmemiştir. Ona göre Ma'mer'in hata yaptığını söyleyenler herhangi bir delil sunmamışlardır. Bununla beraber İbn Hazm, Ma'mer b. Râşid'in sika ve güvenilir birisi olduğunu da

\footnotetext{
72 Ebû Bekr Şemsü'l-Eimme Muhammed b. Ebî Sehl Ahmed es-Serahsî, el-Mebsût (Beyrut: Dâru'lMa'rifeMa'rife, 1993), 5: 55.

${ }^{73}$ Ebü'l-Hüseyn Ahmed b. Ebî Bekr Muhammed b. Ahmed el-Kudûrî, et-Tecrîd (Kahire: Dâru’s-Selâm, 2006), 9: 4525.

${ }^{74}$ Ebû Bekr Ahmed b. Alî er-Râzî el-Cessâs, Şerhu muhtasar't-Tahâvî (Beyrut: Dâru'l-Beşâiri'l-İslamiye, 2010), 4: 352.

${ }^{75}$ Cessâs, Şerhu muhtasar Tahâvî, 4: 357.

76 Ebû'l-Kâsım Abdurrahman b. Abdullah b. Ahmed es-Süheylî, er-Ravzü'l-ünüf fî şerhi's-Sireti'nnebeviyye li-İbn Hişam, nşr. Ömer Abdüsselâm es-Selâmî, (Beyrut: Dâruİhyâi't-Turâsi'l-Arabî, 2000), 7: 338.
} 
vurgulamıştır. ${ }^{77}$ Aynı şekilde Hanefi âlimlerinden olan İbnü'l-Hümâm da (ö. 861/1457) Gaylân b. Seleme rivayetini dörtten fazla kadınla evlenmenin caiz olmadığı bağlamında ele almış ve onunla delil getirmiştir. ${ }^{78}$

\section{SONUÇ}

Müslüman olmadan önce dörtten fazla kadınla evli olan kişinin durumu ile ilgili ihtilafın temel nedeni rivayetlerdeki ihtilafa dayanmaktadır. Buna göre Gaylân b. Seleme'nin rivayetini sahih kabul edenler, rivayetin muhtevasına uygun bir hüküm vermişlerdir. Rivayeti muallel görenler ise farklı bir sonuca varmışlardır.

Müslüman olmadan önce dörtten fazla kadınla evli olan bir kişinin, Müslüman olduktan sonra hanımlarından dördünü yanında tutup diğerlerini de boşaması gerekmektedir. $\mathrm{Bu}$ konuda âlimler arasında ittifak vardır. Ancak hanımlarından hangilerini yanında tutacağı ve hangilerini boşayacağı konusunda ihtilaf söz konusudur. İmam Şâfîi ve Ahmed b. Hanbel gibi bazı âlimlere göre kişi, hanımlarından istediği dördünü yanında tutar, diğerlerini ise boşar. İmam Ebû Hanife ve Ebû Yusuf gibi bazı âlimler ise farklı bir görüş ortaya koymuşlardır. Bu âlimlere göre böyle bir meselede daha önce kıyılan nikâhlara bakılmalı ve ona göre hüküm verilmelidir. Bu bağlamda eğer eşlerin nikâhları bir akitte kıyılmısssa bütün hanımların nikâhları geçersiz sayılmakta ve kadınlar boş olmaktadır. Ancak eşlerin nikâhları birbirinden farklı akitlerde kıyılmışsa erkeğin ilk dört hanımını yanında tutması, diğerlerini ise boşaması gerekmektedir.

İmam Şâfiî̀nin ve onun gibi düşünenlerin temel dayanakları Gaylân b. Seleme rivayetidir. Zira onlara göre bu rivayet sened açısından muttasıl ve sahih olup hüccet olmaya uygundur. Ebû Hanife ve onun gibi düşünen âlimler ise Gaylân b. Seleme rivayetinin sened açısından munkatı' olduğunu söylemişler ve rivayetin bu haliyle delil olamayacağını ifade etmişlerdir.

Tespit edebildiğimiz kadarıyla Gaylân b. Seleme rivayeti muttasıl olup delil olarak kullanılmaya uygundur. Çünkü bu rivayet başta İmam Şâfiî olmak üzere birçok hadis âlimi tarafından muttasıl bir senedle rivayet edilmiştir. Ayrıca senedde yer alan râviler, genel olarak hadis münekkitleri tarafından güvenilir kabul edilmiştir. Bununla beraber Gaylân b. Seleme rivayetini destekleyen Kays b. Hâris'in rivayeti gibi başka hadisleri de bulmak mümkündür.

Gaylân b. Seleme rivayetine yapılan tenkitlerin iki noktada yoğunlaştığı görülmektedir. Bunlardan birincisi Zührî'nin söz konusu rivayeti mürsel olarak nakletmesi, ikincisi ise Ma'mer b. Râşid'in mürsel kabul edilen rivayeti hataen muttasıl senedle rivayet etmesidir. Ancak tespitimize göre Zührî bu rivayeti hem mürsel hem de muttasıl olarak nakletmiştir. Ayrıca bu rivayetin bazı muttasıl tariklerinde Zührî bulunmamaktadır. Dolayısıyla Zührî bağlamında yapılan eleştirilerin rivayetin sıhhatine zarar verecek boyutta olmadığını düşünüyoruz. Ma'mer'in hata yaptığ 1 söyleminin de tenkide açık olduğu düşünülebilir. Bu görüşe göre Gaylân b. Seleme ile ilgili Zührî’den iki nakil

\footnotetext{
${ }^{77}$ Ebû Muhammed Alî b. Ahmed b. Saîd b. Hazm el-Endelüsî el-Kurtubî, el-Muhallâ bi'l-âsâr fi şerhi'lMücellâ bi'l-ihtisâr (Beyrut: Dâru'l-Fikr, tsz.), 7: 9.

78 İbnü'l-Hümâm Kemâlüddîn Muhammed b. Abdilvâhid b. Abdilhamîd es-Sivâsî el-İskenderî, Fethü'lkedîr (Beyrut: Dâru'l-Fikr, tsz.), 3: 240.
} 
bulunmaktadır. Bunlardan birincisi çalışmamıza konu olan rivayet, ikincisi ise Gaylân b. Seleme'nin Hz. Ömer döneminde eşlerini boşadığı ile ilgili hadisedir. Bu eleştiriyi yapanlara göre Ma'mer, mürsel olan birinci rivayeti, muttasıl olan ikinci rivayetin senediyle naklederek hata yapmıştır. Ancak Ma'mer b. Râşid genel olarak hadis münekkitleri tarafindan güvenilir kabul edilmiştir. Ayrıca Ma'mer'in her iki rivayeti muttasıl olarak naklettiği de muhtemeldir. Çünkü bu iddiayı öne sürenler, Ma'mer'in hatasını ortaya koyacak ciddi bir delil sunamamışlardır. Bununla beraber Gaylân b. Seleme rivayetinin bazı tariklerinde ne Zührî ne de Ma'mer yer almaktadır. Bundan dolayı Zührî ve Ma'mer' in yer almadığı ve muttasıl olan tariklerin varlığı, Gaylân b. Seleme'nin rivayetini sahih k1lan en kuvvetli delil olarak kabul edilebilir.

Bazı âlimlere göre Hz. Peygamber'in, "Hanımlarından dördünü yanında tut." sözü yeni bir akite veya hanımlardan ilk dördüne delalet etmektedir. Âlimlerin bu görüşünün mezhebî saikle zorlama bir te'vîl olduğu söylenebilir. Ayrıca Gaylân b. Seleme ile ilgili rivayette olduğu gibi bazen içerik, zaman ve mekân bakımından birbirinden farklı iki olay aynı senedle ve bir rivayet olarak nakledilebilmektedir. Bu durum sadece Gaylân b. Seleme rivayetiyle sinırlı değildir. $\mathrm{Bu}$ bağlamda rivayetler değerlendirilirken bu durumun da göz önünde bulundurulması gerektiğini düşünüyoruz.

\section{KAYNAKÇA}

Ahmed b. Hanbel, Ebû Abdillâh Ahmed b. Muhammed b. Hanbel eş-Şeybânî elMervezî, Müsned. Beyrut: Müessesetü'r-Risâle, 2001.

Bağdâdî, Hatîb, el-Kifâye fì ilmi'ri-rivâye. Beyrut: Dâru'l-Kütübi'l-İlmiyye, 2006.

Beyhakî, Ebû Bekr Ahmed b. Hüseyn b. Ali, Ma'rifetü's-sünen ve'l-âsâr. Nşr. Abdülmu'tî Emîn Kale'cî. 15 Cilt. Dımeşk: Dâru Kuteybe, 1991.

Beyhakî, Ebû Bekr Ahmed b. Hüseyn b. Ali, el-Hilâfiyat beyne'l-imâmeyni eş-Şâfî̀ ve Ebî Hanîfe ve ashâbihî. 8 Cilt. Kâhire: er-Ravda, 2015.

Beyhakî, Ebû Bekr Ahmed b. Hüseyn b. Ali, es-Sünenü'l-kübrâ, nşr. Muhammed Abdulkadir Atâ 3. Baskı. 11 Cilt. Beyrut: Dâru'l-Kütübi'l-İlmiyye, 2003.

Bilen, Mehmet, "Sahih hadisin Tanımı Üzerine", Dicle Üniversitesi İlahiyat Fakültesi Dergisi 1 (1999): 247-260.

Bilen, Mehmet, İbn Hacer'in Buhârî Savunusu. Ankara: Ankara Okulu, 2013.

Brown, Jonathan, "Erken Dönem Hadis Münekkitlerinin Metin Tenkidi Yaptığını Nasıl Biliyoruz ve Bulmak Niçin Bu Kadar Zor?”, Trc. Salih Kesgin. Usûl: İslam Araştırmaları, 25 (Ocak-Haziran 2016): 256-310.

Buhârî, Ebû Abdillâh Muhammed b. İsmâîl b. İbrâhîm el-Cu'fî̀, et-Târîhu'l-kebîr. Nşr. Mustafa Abdulkadir Ahmed Atâ. 2. Bask1 9 Cilt. Beyrut: Dâru'l-Kütübi'l-İlmiyye, 2008.

Buhârî, Ebû Abdillâh Muhammed b. İsmâîl b. İbrâhîm el-Cu'fî, et-Târîhu'l-evsat. Nşr. Teysîr b. Sa'd. 5 Cilt. Riyâd: Dâru'r-Rüşd, 2005.

Cessâs, Ebû Bekr Ahmed b. Alî er-Râzî, Şerhu Muhtasar't-Tahâvî. 8 Cilt. Beyrut: Dâru'l-Beşâiri'l-İslamiye, 2010.

Cezâirî, Tahir, Tevcîhü'n-nazar ilâ usûli'l-eser. Nşr. Abdulfettâh Ebû Gudde, 2. Bask1. Beyrut: Dâru'l-Beşâiri'l-İslâmiyye, 2009. 
Dârekutnî, Ebü'l-Hasan Alî b. Ömer b. Ahmed, Sünen. 5 Cilt. Beyrut: Müessetü'rRisâle, 2004.

Dârekutnî, Ebü'l-Hasan Alî b. Ömer b. Ahmed, el-İlelü'l-varide fi'l-ehâdîsi'n-nebeviyye. 10 Cilt. Beyrut: Müessesetür'r-Reyyân, 2011.

Demircan, Adnan, "Câhiliyye ve Hz. Peygamber Döneminde Çok Kadınla Evlilik", Istem 1/2 (2003): 9-32.

Doğanay, Süleyman, Râvi Tasarruflarının Doğurduğu Problemler. İstanbul: İSAM Yayınları, 2009.

Dümeynî, Misfir b. Gurmullah, Hadis'te Metin Tenkidi Metodları. Trc. Çelebi, İlyasBebek, Adil-Yücel-Ahmet. İstanbul: Kitabevi Yayınları, 1997.

Düzenli, Muhittin, Hadislerde Gizli Kusurlar. İstanbul: İSAM Yayınları, 2016.

Ebû'l-Kâsım Abdurrahman b. Abdullah b. Ahmed es-Süheylî, er-Ravzü'l-ünüffì şerhi'sSireti'n-nebeviyye li-İbn Hişam, nşr. Ömer Abdüsselâm es-Selâmî. Beyrut: Dâru İhyâi'tTurâsi'l-Arabî, 2000.

Engin, Sezai, "Hadisin Tashîhinde Sened ve Metin Sihhat ilişkisine İllet ve Şâz Bağlamında Metodolojik Bir Yaklaşım”, Sakarya Üniversitesi Ilahiyat Fakültesi Dergisi 17/31 (Haziran 2015): 141-165.

Erman, Uğur, Ehl-i Hadîs ve Ehl-i Re’y Arasında Yaşanan Polemiklerin Cerh ve Ta'dîl İlmine, Dönemin Te'lîfâtına ve Sosyal/Beşerî İlişkilere Yansıması (Hicrî III. Asır), eŞarkiyat İlmi Araştırmalar Dergisi, 9/18 (Kasım 2017): 990-1010.

Ertürk, Mustafa, Metin Tenkidi. 2. Baskı. Ankara: Fecr Yayınları, 2011.

Fahl, Mâhir Yâsîn, Eseru ileli'l-hadîs fì ihtilâfi'l-fukahâ. Ammân: Dâru Ammâr, 2000.

Görmez, Mehmet, Sünnet ve Hadisin Anlaşllmass ve Yorumlanmasinda Metodoloji Sorunu. 5. Bask1. Ankara: OTTO Yayınları, 2014.

Gürler, Kadir, Ehl-i Hadisin Düşünce Yapısı İlk Dönem Ehl-i Hadis Örneği. Bursa: Emin Yayınlar1, 2007.

Habîb, Muhammed b., el-Mühabber. Nşr. Ilse Lichtenstädter. Beyrut: Dâru'l-Âfâki'lCedîde, tsz.

Hâkim, Ebû Abdillâh Muhammed b. Abdillâh b. Muhammed en-Nîsâbûrî, Ma'rifetü ulûmi'l-hadîs. Beyrut: Dâru'l-Kütübi'l-İlmiyye, 1977.

Hallaq, Wael B., "Nebevi Hadisin Sihhati: Yapay Bir Problem", Trc. Hüseyin Hansu, HÜIFD 7/9 (2016): 137-151.

Irâkî, Ebü'l-Fazl Zeynüddin Abdürrahim b. Hüseyin, et-Takyid ve'l-izah şerhu mukaddimeti İbni's-Salah. 5. Baskı Beyrut: Müessesetü'l-Kütübi's-Sakâfiyye 1997.

İbn Abdilber, Ebû Ömer Cemâlüddîn Yûsuf b. Abdillâh b. Muhammed, en-Nemerî, etTemhîd. Nşr. Mustafa b. Ahmed- Muhammed b. Abdülbekîr. 24 Cilt. Mağrib: Vizâretu Umûm'il-Evkâf, 1387.

İbn Ebî Hâtim, Ebû Muhammed Abdurrahmân b. Muhammed b. İdrîs er-Râzî, el-Cerh ve 'ta 'dîl. Nşr. Mustafa Abdulkâdir Atâ, 2. Bask1. 10 Cilt. Beyrut: 2010.

İbn Ebî Hâtim, Ebû Muhammed Abdurrahmân b. Muhammed b. İdrîs er-Râzî, el-ìlel. Nşr. Ebû Ali en-Nâzîf. 2 Cilt. Beyrut: Dâru'l-Kütübi'l-İlmiyye, 2006. 
İbn Hacer, Ebü'l-Fazl Şihâbüddîn Ahmed b. Alî b. Muhammed el-Askalânî, Nüzhetü'nnazar. Kahire: Dâru İbn Receb, 2006.

İbn Hacer, Ebü'l-Fazl Şihâbüddîn Ahmed b. Alî b. Muhammed el-Askalânî, Tehzîbü'tTehzîb. 14 Cilt. Beyrut: Dâru'l-Fikr, 1984.

İbn Hacer, Ebü'l-Fazl Şihâbüddîn Ahmed b. Alî b. Muhammed el-Askalânî, Telhîșü'lhabîr fì tahrîci ehâdîși'r-Râfi 'iyyi'l-kebîr. 4 Cilt. Beyrut: Dâru'l-Kütübi'l-İlmiyye, 1989.

İbn Hacer, Ebü'l-Fazl Şihâbüddîn Ahmed b. Alî b. Muhammed el-Askalânî, Muvâfakatü'l-hubri'l-haber fî tahrîci ehâdîsíl'l-Muhtașar. 2 Cilt. Riyad: Mektebetü'rRüşd, Riyâd 1993.

İbn Hazm, Ebû Muhammed Alî b. Ahmed b. Saîd el-Endelüsî el-Kurtubî, el-Muhallâ bi'l-âsâr fi şerhi'l-Mücellâ bi'l-ihtisâr. 12 Cilt. Beyrut: Dâru'l-Fikr, tsz.

İbn Kudâme, Ebû Muhammed Muvaffakuddîn Abdullāh b. Ahmed b. Muhammed elCemmâîlî el-Makdisî, Muğnî. 10 Cilt. Beyrut: Dâru İhyâi’t-Turâsi'l-Arabî, 1985.

İbn Mâce, Ebû Abdillâh Muhammed b. Yezîd Mâce el-Kazvînî, Sünen. Nşr. Arnavut, Şuayp - Mürşid, Adıl - Karabelli, Muhammed Kâmil. 5 Cilt. Beyrut: Dâru'r- Resâili'lAlemiyye, 2009.

İbn Sa'd, Ebû Abdillâh Muhammed Menî‘ el-Kâtib el-Hâşimî el-Basrî el-Bağdâdî, etTabakâtü'l-kübrâ. Nşr, İhsân Abbâs. 8 Cilt. Beyrut: Dâru Sadr, 1968.

İbnü'l-Cevzî, Ebû'l-Ferec Abdurrahman b. Ali, Kitâbü'l-mevzûât. Beyrut: Dâru'l-Fikr, 1983.

İbnü's-Salâh, Ebû Amr Takıyyüddîn Osmân b. Salâhiddîn Abdirrahmân b. Mûsâ eşŞehrezûrî, Ma'rifetu ulûmi'l-hadîs. 3. Bask1. Beyrut: Dâru'l-Kütübi'l-İlmiyye, 2010.

Keleş, Ahmet, Hadis Illminde Metin Tenkidi Örnekleri. Ankara: Fecr Yayınları, 2017.

Köktaş, Yavuz, "Hadiste İllet: Ümmetin Faziletiyle İlgili Bir Hadîsin Değerlendirilmesi”, Ç. U. Illahiyat Fakültesi Dergisi, 2/2 (Temmuz-Aralık 2002): 41-73.

Kudûrî, Ebü'l-Hüseyn Ahmed b. Ebî Bekr Muhammed b. Ahmed, et-Tecrîd. 12 Cilt. Kahire: Dâru's-Selâm, 2006.

Küçük, Raşit. "Metin, Türkiye Diyanet Vakfi İslâm Ansiklopedisi. 29: 411-414. Ankara: TDV Yayınları, 2004.

Menbecî, Cemâlüddîn Ebû Muhammed Ali b. Ebî Yahyâ, el-Lübâb fíl-cem'i beyne'ssünne ve'l-kitâb. 2 Cilt. Dımeşk: Dâru'l-Kalem, 1994.

Mizzî, Ebû'l-Haccâc Cemâlüddîn Yûsuf b. Abdirrahmân b. Yûsuf, Tehzîbü'l-Kemal fî esmai 'r-ricâl. nşr. Beşşâr Avvâd Maruf. 35 Cilt. Beyurt: Müessesetü'r-Risâle, 1980.

Özafşar, M. Emin, "Kültür Tarihimizde Rey-Eser Çatışması (Dini, Psikolojik, SosyoKültürel Temelleri)", Ankara Üniversitesi Illahiyat Fakültesi Dergisi, 2000/41, (2000): 225-273.

Özşenel, Mehmet, İlk Dönem Hadis-Rey Tartışmaları Şeybânî Örneği. 2. Bask1. İstanbul: İFAV Yayınları, 2017.

Sehâvî, Ebü'l-Hayr Şemsüddîn Muhammed b. Abdirrahmân b. Muhammed, el-Cevâhir ve'd-dürer fî tercemeti Şeyhi'l-İslâm İbn Hacer. 3 Cilt. Lübnan: Dâru İbn Hazm 1999. 


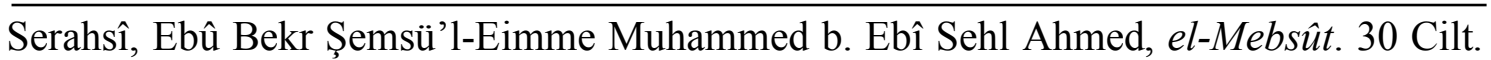
Beyrut: Dâru'l-Ma'rife, 1993.

Şâfî̂, Ebû Abdillâh Muhammed b. İdrîs b. Abbâs, er-Risâle, nşr. Ahmed Şakir. Kahire: Dâru'l-Hadîs, 2016.

Şâfiî, Ebû Abdillâh Muhammed b. İdrîs b. Abbâs, el-Ümm. 8 Cilt. Beyrut: Dâru'lMa'rife, 1990.

Şâtıbî, İbrahim b. Musa, el-Muvâfakât. 7 Cilt. Kâhire: Dâru İbn Affân, 1997.

Tahâvî, Ebû Ca'fer Ahmed b. Muhammed b. Selâme el-Ezdî el-Hacrî el-Misrî, Şerhu maânî'l-âsâr. 5 Cilt. Kahire: Âlemü'l-Kütüb, 1994.

Tirmizî, Ebû Îsâ Muhammed b. Îsâ, Sünen. nşr. Beşşâr Avvâd Marûf. 6 Cilt. Beyrut: Dâru'l-Garbi'l-İslâmî, 1998.

Uyarı, Ahmet, "Hadisleri/Sünneti Anlamada Farklı Yaklaşımlar (Ehl-i Hadis Ve Ehl-i Re'y Ekolleri)", Bilimname 2004/2 (Haziran 2004): 29-44.

Yıldırım, Enbiya, Hadiste Metin Tenkidi. İstanbul: Rağbet Yayınları, 2009.

Zehebî, Ebû Abdillâh Şemsüddîn Muhammed b. Ahmed b. Osmân et-Türkmânî elFârikī, Siyeru a'lâmi'n-nübelâ. 18. Cilt. Kahire: Dâru'l-Hadîs 2006. 